Rhode Island College

Digital Commons @ RIC

April 2021

\title{
The Effect of Green Space on the Physiologic Function of the Adult: A Systematic Review
}

Brenna Franco

Follow this and additional works at: https://digitalcommons.ric.edu/etd

Part of the Nursing Commons

\section{Recommended Citation}

Franco, Brenna, "The Effect of Green Space on the Physiologic Function of the Adult: A Systematic Review" (2021). Master's Theses, Dissertations, Graduate Research and Major Papers Overview. 380. https://digitalcommons.ric.edu/etd/380

This Major Paper is brought to you for free and open access by the Master's Theses, Dissertations, Graduate Research and Major Papers at Digital Commons @ RIC. It has been accepted for inclusion in Master's Theses, Dissertations, Graduate Research and Major Papers Overview by an authorized administrator of Digital Commons @ RIC. For more information, please contact digitalcommons@ric.edu. 
THE EFFECT OF GREEN SPACE ON THE PHYSIOLOGIC FUNCTION OF THE ADULT:

A SYSTEMATIC REVIEW

by

\section{Brenna Franco}

A Major Paper Submitted in Partial Fulfillment

of the Requirements for the Degree of

Master of Science in Nursing

in

The School of Nursing

Rhode Island College

2021 


\begin{abstract}
Environmental greenness is often associated with improved psychological outcomes, but the use of green space as a protective factor for maintaining physiologic health is understudied. However, growing evidence exists on the benefit of greenness on physiologic health. The purpose of this systematic review was to evaluate the effect of green space on the physiologic function of the adult. Cohort studies were searched for that had all elements of inclusion criteria. Six final studies were included in this systematic review utilizing PRISMA guidelines and CASP tool for cohort studies. Data from the studies was collected and a cross study analysis was conducted to compare all studies and assess for themes in study outcomes. Results of this review demonstrate that green space has a protective effect on physiologic health. Areas with higher levels of greenness are associated with lower prevalence of central obesity, diabetes mellitus, and self-reported rates of cardiovascular disease and stroke as well as decreased rates of mortality from cancers, and kidney and respiratory diseases. Implications of this study include the importance in understanding risk factors for development of disease. Awareness of a patient's environment that includes natural spaces should be identified as a potential risk factor for the development of cardiovascular illness, obesity, and diabetes mellitus.
\end{abstract}




\section{Acknowledgements}

I want to thank my amazing family and friends for all of their love, support, and encouragement over these past two years. Thank you for keeping me sane, grounded, and motivated. Special thanks to my love for keeping me laughing through it all. I love you all! 


\section{Table of Contents}

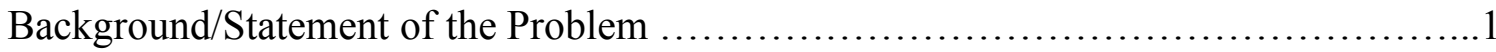

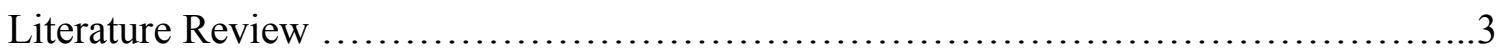

Theoretical Framework ..................................................... 12

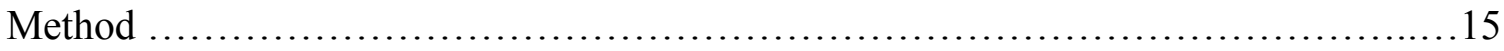

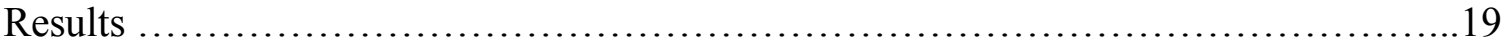

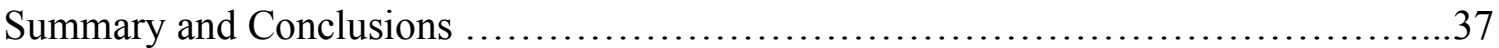

Recommendations and Implications for Advanced Nursing Practice .................40

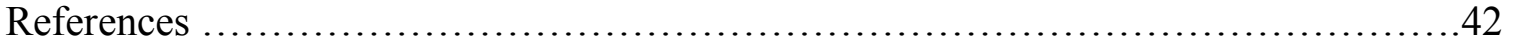

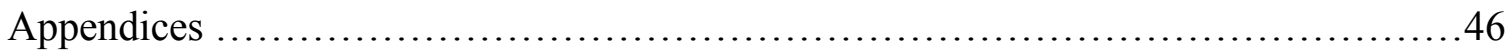


The Effect of Green Space on the Physiologic Function of the Adult: A Systematic Review

\section{Background/Statement of the Problem}

Modern nursing utilizes a combination of scientific and holistic methods to care for patients through merging the basics of nursing developed by Florence Nightingale with the most recent high acuity skill sets for inpatient care. However, due to the busy and often highly acute nature of inpatient care, simple therapeutic methods, such as access to fresh air, light, and nature are often excluded from a patient's care. Green spaces are considered a vital part in the development of towns and cities for aesthetics and recreation. Modern city planning includes the addition of green spaces because of the importance they play in ecological balance and promoting residential well-being (Russo \& Cirella, 2018). However, this well-being is usually studied from the psychological angle, but understanding the precise physiologic benefits of green spaces is underdeveloped. Brown, Barton and Gladwell (2013) found that simply viewing images of nature caused increased heart rate recovery following the introduction of a particular stressor. Additionally, Twohig-Bennet and Jones (2018) found that green space was associated with decreased cortisol levels, rates of diabetes mellitus, stroke, cardiovascular disease and even overall mortality rates. This poses the question, how do nonpharmacological factors, specifically access to green space impact the physiologic health of the adult?

Defining green space can be a difficult task. Depending upon the location, anything from a park to the dense foliage of a forest is considered green space. However, in general, green space can be used to describe an area that is made up of some combination of natural elements and vegetation (Taylor \& Hochuli, 2017). Measurement 
tools can be used to refine the process of defining green space for a particular study. An objective way greenness can be measured is by using the Normalized Difference Vegetation Index, or NDVI. The NDVI is a satellite imagery tool used to measure the density of green space in a particular area ("Measuring Vegetation [NDVI \& EVI]," 2000). NDVI is measured on a scale from -1 to +1 . A score of -1 is indicative of natural spaces that do not possess greenery, such as water, and a score closer to +1 is indicative of the highest density of green leaves. A score of 0 means no source of natural spaces, greenness, or water exists, and indicates urbanization.

The purpose of this study was to examine the effect of green space on the physiologic function of the adult. A systematic review was conducted to determine the impact that greenness has on health outcomes. Greenness was measured using the NDVI in all of the included studies and patient's weight, cardiovascular health, incidence of diabetes, and overall mortality rates were determined as outcomes.

Next, a review of literature will be presented. 


\section{Literature Review}

The databases that were utilized in this literature review include CINHAL, PubMed, and Google Scholar. The major keywords used in locating research articles were "green space," "green space measurement," "nature," "outdoors," "older adult health," and "physiologic health." Only studies completed in the English language were considered for this review.

\section{Measuring Green Space}

Subjective Green Space. Green space must first be understood as a measurable factor. There are many ways that green space can be measured, and each author determines the tool they will use to define green space for a study. One common way green space is measured is through subjective assessment by the study participant as seen in Twohig-Bennet and Jones' (2018) study. In this case, participants of the study would define their surrounding green space as more or less green. Other studies create a green space and use this manufactured setting as the green space variable. Raanaas, Patil, and Hartig (2011) and Raanaas, Patil, and Alve (2016) used this method when evaluating a patient's perceived health. The authors in these studies defined a participant's exposure to green space as either a panoramic view, or a blocked view. This method was also used with Brown et al. (2013) where the participants were shown images of nature on a screen. In this study, green space was defined as a particular set of images.

Objective Green Space. Data measurements can be taken to obtain a specific level of green space. Commonly used methods of measuring green space include calculating the NDVI from satellite imagery. Calculating NDVI is the most common method for determining levels of vegetation (Altaweel, 2017). One of the instruments 
used to calculate NDVI is a moderate-resolution imaging spectroradiometer. This particular satellite instrument is able to detect near visible and infrared light. Plants absorb visible light and reflect near infrared light, and the satellite is able to detect this light. NDVI is then calculated based on these satellite findings (Altaweel, 2017). NDVI is calculated on a scale from -1 to +1 . The closer to +1 indicates more dense foliage, zero indicated no green space, and -1 indicates blue space (water) ("Measuring Vegetation [NDVI \& EVI]," 2000).

There are many other types of satellites that can also be used to measure vegetation. The readings from these satellites are recorded in various databases. These databases are a part of governmental land data and are different for each geographic region and country. The data recording green space can then be used for various research studies. Twohig-Bennet and Jones (2018) included research in their systematic review that utilized the Center for Ecology and Hydrology $(\mathrm{CeH})$ Land Cover Map, which is the land cover map database that is used for Great Britain (Land Cover Map 2015, n.d.).

\section{Perceived Health Outcomes}

The concept of perceived or self-reported health was a study focus for patients undergoing rehabilitation in a facility in Norway. Raanaas, Patil, and Hartig (2011) conducted a longitudinal quasi-experimental study that involved the assessment of pulmonary and cardiac patients in a rehabilitation center in Norway. The study examined how these patients rated the effect that varying nature views had on their physical health. In the study, most patients were admitted to the rehabilitation center from their homes when referred by their physician or were admitted directly from an inpatient setting. The patients were assigned rooms with varying views of the outdoors ranging from panoramic 
views to entirely blocked views. The patients completed surveys that included questions about their emotional well-being, time spent walking and performing leisure activities, and self-reported health. Raanaas, Patil, and Hartig (2011) found that cardiac patients with a blocked view of nature reported the least amount of improvement in physical health during their time in the rehab, whereas the pulmonary patients with a panoramic view reported the greatest amount of improvement between week two and four of the study. Although this study found a relationship between recovery from illness and views of nature, it is difficult to measure the significance of the patient's recovery, as the researchers did not include the details of the rehabilitation program and used cardiac and pulmonary rehabilitation patients, which are unmatched groups.

In a similar study conducted by Raanaas, Patil, and Alve (2016) a phenomenological study approach was utilized in an attempt to find the meaning that nature had on a patient's recovery. Again, the patient's perceived health was the focus of the study and is therefore not measurable. However, unlike the Raanaas, Patil, and Hartig (2011) study, this study did explicitly state that the rehabilitation program was for patients with generally stable but chronic illnesses and focused on exercising to improve physical function. Researchers conducted focus groups and individual interviews in which participants in the study were asked how they felt having access to nature affected their recovery. A strong link between the patient's emotional well-being and physical recovery existed. Natural elements were shown to trigger health promotion activities and mentally prepare patients for partaking in rigorous physical rehabilitation activities. In summary, Raanaas, Patil, and Alve (2016) found that it was difficult to separate mental health from physical health because the one is dependent upon motivating the other. 
White et al. (2019) conducted a longitudinal study in England that examined the relationship between time spent outdoors and self-reported physical health and wellbeing. The study was conducted through a National Environment Survey and green space was determined using the Generalized Land Use Database (GLUD). GLUD is a database that contains statistics about the specific land types throughout areas in England ("Generalized Land Use Database", 2007). The GLUD was used to determine the area of the participant's neighborhood that is covered by green spaces and gardens (White et al., 2019). The totals of the green space are then recorded as a density level. The study asked participants to respond with their perceived views on their health as 'very bad,' 'bad,' 'fair,' 'good,' or 'very good.' It was found that participants reported they had 'good' or 'very good' health if they spent greater than 119 minutes a week in the green spaces. The responses for self-reported health were closely associated with a participant's use of medical services including calls to a primary care provider and hospital visits.

Furthermore, positive correlations with self-reported health continued as participants increased their amount of time in green spaces. This study provided insight into not only the positive correlation between green space and self-reported physiological health, but also a direct link between increasing time spent in green space and improved physical health.

\section{Physical Activity and Green Space}

Positive Relationship. In a systematic review conducted by den Braver et al., (2018) 109 articles were analyzed to determine the factors that affect incidence of type 2 diabetes mellitus. The authors highlight that in addition to the well-understood risk factors for developing type 2 diabetes such as poor diet and lack of exercise, decreased 
access to an outdoor green space can also increase the risk of diabetes. The researchers further assessed particular environments that encourage physical activity and how the environment and activity have an effect on the outcome of diabetic prevalence. The analysis found that the relationship between increased physical activity resulting from access to green space and decreased incidence of diabetes had a stronger correlation than that between poor diet and increased incidences of diabetes. Ultimately, the research found that more green space tended to be associated with lower risks of type 2 diabetes mellitus. Although this study does not focus specifically on the older adult population, it sheds a light on the relationship between green space and the prevention of disease, in this case type 2 diabetes mellitus. Furthermore, implications of this study went on to suggest that city planning include the addition of green spaces as a means to increase physical activity and reduce incidences of type 2 diabetes mellitus (den Braver et al., 2018).

Absent Relationship. Negative or absent relationships between levels of green space and physical activity have also been studied. This relationship is important to understand because it allows researchers to recognize that exposure to green space does not equate to increased physical activity. Although den Braver et al. (2018) found through systematic review that a positive relationship between green space and physical activity exists, Ord, et al. (2013) obtained a directly conflicting report when conducting a similar study in Scotland. The study analyzed findings from the Scottish Health Survey which asked 2,269 participants to answer questions about their level of physical activity and where the physical activity was performed. Additionally, the surveyors measured the density of green space in the respondent's neighborhood by obtaining records from the 
Census Area Statistics in Scotland. Ultimately, the study found no correlation between level of green space in a participant's area and level of physical activity (Ord, et al., 2013). However, this study does not address any level of physical health other than activity level. It is necessary to distinguish this fact in order to understand that green space is its own entity when it comes to determining variables that have a positive impact on physiological health.

Physical Activity versus Reported Health. Comparing levels of physical activity to reported health outcomes clarifies the difference between measuring frequency of physical activity as it relates to access to green spaces and how physiologic health relates to green spaces in the absence of physical activity. Maas (2008) found that an inverse relationship in the Netherlands between cycling and walking and levels of green space existed. This appears to be related to increased levels of cycling and walking in urban areas as a means of transportation. This means that although these urban areas lack green space, activity levels are increased. However, Maas (2008) also found that aspects of cardiovascular health were improved when living spaces included increased levels of green spaces. Green space was determined from data obtained by the National Land Cover Classification database. This database collects data about the type of land in a particular area and if it is more green or urban. Participants who lived in areas with $90 \%$ green space had a reported rate of 4.0 per 1000 persons with cardiovascular disease; however, this number was higher in areas with lower levels of green space. Cardiovascular disease rates in areas where $10 \%$ of the surrounding space were considered green spaces were 4.7 per every 1000 person. The correlation is similar for 
rates of hypertension, stroke and brain hemorrhage. This supports that green space has a positive impact on physiologic health even in the absence of physical activity.

\section{Physiologic Health Outcomes}

In a randomized crossover study conducted by Brown et al. (2013) a measure of heart rate variability was examined to assess the effects of green space on physiologic function. The study defines heart rate variability (HRV) as an accurate, noninvasive measurement of the autonomic nervous system. The autonomic nervous system is responsible for bodily controls that are not consciously controlled by the brain, such as digestion, heart rate, and breathing (McCorry, 2007). When introduced to a stressor, the participant's ( $\mathrm{n}=25,7$ males, 18 females) heart rate would increase as the autonomic nervous system was stimulated (Brown et al., 2013). This increase in heart rate was noted on an electrocardiogram. When the stressor was removed and the participant was shown views of nature, their heart rate would decrease. The difference between the elevated and recovered heart rate is known as heart rate variability. Increased HRV is associated with improved health as the autonomic nervous system is able to respond to changes in external stimuli.

Participants in the Brown et al. (2013) study were placed in a controlled environment and were continuously monitored with an electrocardiogram, blood pressure cuff and respiratory strap. A baseline autonomic function was obtained after the participants had been at rest for ten minutes. Participants were then observed while attempting to solve a digit span test where numbers flashed rapidly on a screen in front of them and then tasked with writing the numbers down in the correct order that they had appeared. Under this controlled mental stressor that was designed to elicit a 
cardiovascular stress response, it was discovered that HRV increased during the recovery of the stressor after the participants viewed images of nature. This suggests that the viewing of green spaces has a calming effect that allows the autonomic nervous system to recover rapidly. The implications of this study also extend to the potential that green spaces could have an effect on overall cardiovascular function. This study was unique because it allowed the researchers to isolate the effect green space has on physiologic health while eliminating any forms of physical activity.

Twohig-Bennett and Jones (2018) conducted a systematic review that compared green space to health outcomes. The study discusses four hypotheses that link nature and health. The first hypothesis is that green areas promote health due to the ability to be physically active in these spaces. The second focuses on emotional health and says that green spaces can be forums for social events and therefore improve mental well-being. The third hypothesis focuses on the effect that sunlight has on mood and vitamin D. The final, and most relevant hypothesis is the "Old Friends" hypothesis, which states that there are microorganisms found only in nature, that if a person is exposed to, will aide in the development of increased immunity and improved inflammatory responses. This implies a biological connection between the outdoor spaces and physical health. TwohigBennett and Jones (2018) went on to analyze 143 studies and found that the incidence of type 2 diabetes mellitus and cardiovascular mortality was reduced for those who had exposure and access to green space. Neighborhood green space was considered for this review and was measured using a variety of tools such as the NDVI, and the CeH land cover map, as well as participant's subjective opinions about the quality of green space in their surrounding neighborhood. The study concludes with the analysis that green space 
exposure has statistically significant impacts on physical health including, but not limited to, reduced rates of diabetes and cardiovascular mortality. The odds ratio for developing diabetes in an area of low green space was found to be $85 \%$ versus the odds ratio of developing diabetes in areas of high green space, which was reduced to $61 \%$. Additionally, cardiovascular mortality in areas of low green space was $93 \%$ but in areas of high green space, mortality was reduced to $76 \%$ (Twohig-Bennett \& Jones, 2018). Next, the theoretical framework will be presented. 


\section{Theoretical Framework}

Theoretical and conceptual frameworks are frequently utilized as a template to guide nursing research. The theoretical framework chosen to guide this study is the Environmental Theory or Environmental Adaptation Theory, which emerged in the 1800s as a foundation of Florence Nightingale's practice. In her practice, Nightingale transcribed and compiled her research while caring for her patients. Florence Nightingale grounded her nursing practice in adjusting five particular aspects of care. These aspects include light, ventilation, cleanliness, temperature, and noise, and became the framework for her philosophy of nursing (Nightingale, 2010). She began to recognize patterns of more positive patient outcomes when the patients were treated in areas where cleanliness, light and ventilation were of the highest possible quality. These concepts may seem rudimentary, but they act as a foundation for modern nursing. Although Nightingale did not explicitly refer to these elements as nursing theory, it has been identified that extracting elements of her philosophy act as a grand theory for holistic nursing (Hegge, 2013).

In relation to nursing and aspects of green space, Nightingale observed many positive interactions between nature and healing. In Nightingale's published notes, she describes the above elements and how they aid the patient. She even speaks directly of flowers saying that cut flowers can absorb carbonic acid and give off oxygen (Nightingale, 2010). One of Nightingale's most passionate ideologies was to keep the "air within as pure as the air without" (Nightingale, 2010, p. 9). Nightingale believed that the air we breathe should be as pure and fresh as possible. She believed in opening windows and avoiding smoke, and she disputed the previously believed idea that night air was 
somehow poisonous. She was one of the first people to understand that proper ventilation and airflow was necessary to clean out homes and hospital wards. With the development of technology, these concepts of airflow are now widely used and understood in day-today patient care. Patients are placed in negative or positive pressure rooms based on patient illness. Clearly, Nightingale's observations have driven many aspects of modern nursing and medicine.

In a study performed in Kenya, Nightingale's Environmental Theory was applied to patients diagnosed with tuberculosis. The study concluded that applying the basic concepts of Nightingale's theory would be beneficial in the care of patients with tuberculosis, in particular, extreme drug-resistant tuberculosis (Kamau et al., 2015). The study found that the concepts of paramount importance to treating the patient diagnosed with tuberculosis were cleanliness and light as tuberculosis bacterium has been identified as light sensitive. Therefore, the isolation wards were made sanitary and equipped with as much light as the medical professionals could offer (Kamau et al., 2015). The study examines one case study of a 61-year-old woman diagnosed with tuberculosis that was placed in the isolation unit in Kenya for three months and was treated with dose-observed therapy. The patient's room conditions required natural, non-artificial light for patient comfort, clean air and ventilation, all aspects that are a part of Nightingale's theory. After a few weeks, the patient was noted to have improved signs and symptoms of active disease. Her fever had subsided, and she was beginning to gain weight and have decreased anorexia (Kamau et al., 2015). Although the individual case study was still underway at the time of submission, and therefore patient outcomes could not be identified, it is significant to note that the Nightingale model was applied to the Kenyan 
nurses plan of care in the development of the clinic. This theory will be an appropriate framework to utilize for the purpose of this research, as at its core the adjustment of a patient's environment is implemented in order to obtain a more desirable health outcome.

Nightingale's theory applies to the concept of green space as a determinant for physiologic health due to the fact that green space naturally includes ventilation and light by means of the outdoors.

Next, the methods will be presented. 


\section{Methods}

\section{Purpose}

The purpose of this study is to examine the effect of green space on the physiologic function of the adult. In order to determine the outcomes of this question, a systematic review of current literature will be performed. Studies examined will be longitudinal, cohort studies to collect more data about this topic.

\section{Inclusion/Exclusion Criteria}

Inclusion criteria for the study included (a) element of green space, (b) use of NDVI as a measurement tool for green space, (c) adults 18 years of age and older, (d) physiologic health outcomes, and (e) have occurred within the past ten years.

Exclusion criteria for the study included (a) psychological or psychosocial health outcomes, (b) pediatric subjects under the age of 18 years old, (c) green space not measured with the use of the standardized NDVI tool, and (d) studies greater than ten years old.

\section{Search Strategy}

A detailed search was performed using CINHAL (Cumulative Index to Nursing and Allied Health Literature) and Google Scholar to conduct the study search. The keyword NDVI was input which automatically generated studies that included green space. "Physiologic health" and "health outcomes" were then added to refine the search to medical study findings. Finally, the word "adult" was added to refine the search to studies with adult subjects only. The search was also restricted to studies conducted from 2010-2020. 


\section{PRISMA}

The systematic review follows the guidelines that are outlined in the PRISMA (Preferred Reporting Items for Systematic reviews and Meta-Analysis) statement. The PRISMA statement is used to assist authors of systematic reviews with the method of reporting findings and ensure quality articles are used for data collection. The statement consists of a four-phase diagram for authors to follow to improve their data reports (Appendix A) (Moher et al., 2009). A 27-item checklist in the PRISMA statement focuses on the organization of items to include when reporting a systematic review. The items are grouped into title, abstract, introduction, methods, results, discussion, and funding (Appendix B). All 27 qualifications and all levels of the diagram were followed when obtaining the studies used for the final analysis of this paper.

\section{Data Collection}

Data collection tools unique to this paper were used to organize research data. The data collected includes the title, author, purpose and methods of the study, population being studied, including size and demographic, and level of greenness identified by the study using the NDVI scale and results of the study (Appendix C). Studies that assess variability in green spaces, meaning residential areas that have more or less variability between green and urbanization, will be identified. Physiologic outcomes of each study are then identified as rates. The physiologic outcomes in the studies researched examine prevalence of cardiovascular health indicators, diabetes, rates of obesity or overweight participants, and overall mortality rates. 


\section{Critical Appraisal}

Critical appraisal of the studies included in the research was completed to ensure trustworthiness and decrease bias. The CASP (Critical Appraisal Skills Programme) critical appraisal tool was utilized to evaluate the study design, methodology and results (Appendix D). Specifically, the CASP tool for cohort studies was utilized because the studies examined were cohort, longitudinal or observational studies.

\section{Cross Study Analysis}

After the studies were critically appraised, data synthesis and cross study analysis was completed. The results were cross analyzed to evaluate the impact level of greenness measured with the NDVI scale has on physiologic health. The NDVI scale in the cross study analysis includes only the upper quartile (dense green) and the overall physiologic outcome seen from each individual study. The outcome is presented as an increase or decrease in rates of physiological illness as found from each individual study. The overall impact is identified as positive or negative. The factors that are measured include cardiovascular disease risk, diabetes incidence, obesity incidence and mortality rates. Any additional findings, including, but not limited to, stroke, respiratory illness and kidney disease were listed if found by the original study as being statistically significant. Table 1 displays the cross-study analysis tool created by the author of this paper. Table 1.

Cross Study Analysis

\begin{tabular}{|c|c|c|c|}
\hline Title and Author & NDVI Range & $\begin{array}{c}\text { Overall Physiologic } \\
\text { Outcome }\end{array}$ & $\begin{array}{c}\text { Outcome Negative } \\
\text { or Positive }\end{array}$ \\
\hline & & & \\
& & & \\
\hline
\end{tabular}


Next, the results will be presented. 


\section{Results}

The cohort studies in this systematic review were selected by utilizing the inclusion and exclusion criteria, as well as the PRISMA flow diagram. The PRISMA flow diagram in Figure 1 displays the selection process for the included studies.

An initial search for "NDVI and adult health" yielded 119 articles. Of those 119 articles there were no duplicates. The 119 articles were screened and the search word "physical" was added before health. This removed 73 articles from the search. There were 46 articles that were screened for eligibility based on inclusion and exclusion criteria. 39 studies were excluded for not following inclusion criteria and one additional study was excluded because NDVI was not the primary measurement used to indicate green space. Six cohort studies were included in the final analysis. 
PRISMA 2009 Flow Diagram

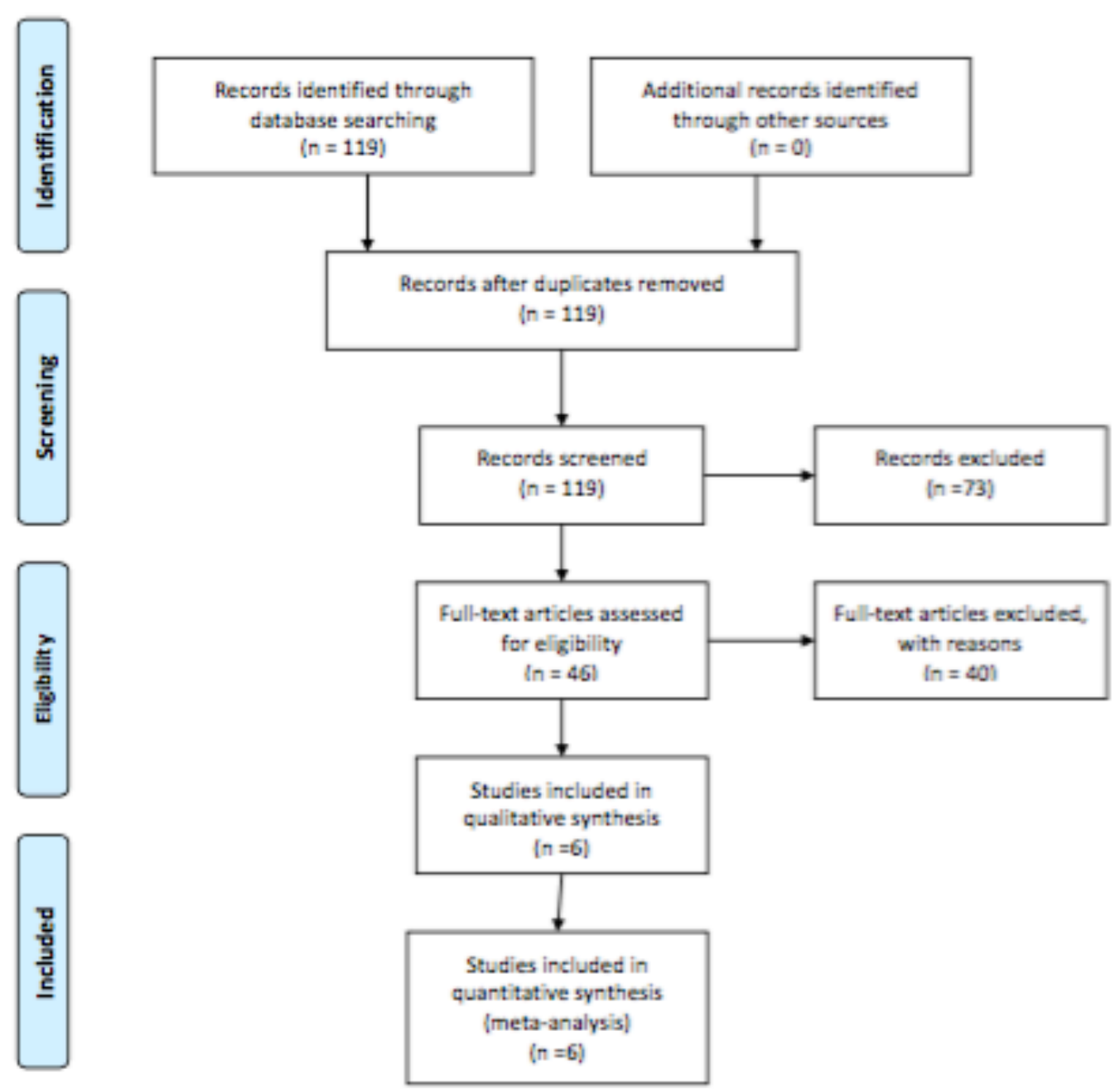

Figure 1: PRISMA Flow Diagram

Each of the six studies included in the final analysis of this review contain data relevant to the outcome of green space's impact on physiologic health. The tables in Appendix D contain cross sectional analysis and provide the study's conclusion whether green spaces had a negative or positive impact on the type of physiologic health that was 
examined in the study. The following information is summarized in data tables (Appendices C 1-6).

\section{Study Results}

James et al. (2016) performed a prospective cohort study to determine if high levels of surrounding residential greenness led to decreased rates of all-cause, cancer, respiratory, and cardiovascular mortality rates (Appendix C1). Participants in this study were enrolled in the Nurses' Health Survey, which began in 1976, and was a biennial survey that was sent out to female adult nurses ages $30-55$. The survey followed the women throughout their lifetime and recorded various health-related exposures, medical diagnoses, and participant deaths. Survey participation was $90 \%$ among those still living each time the survey was completed. 108,630 participants were examined for the James et al. (2016) study. Deaths that occurred between 2000 and 2008 were tracked for cause of death by reviewing participants' medical records. A physician reviewed medical records and the primary cause of death was classified according to the International Classification of Disease, Ninth Revision (ICD-9). ICD-9 classifications of infectious and parasitic disease, cancer, diabetes, neurodegenerative disease, coronary heart disease, stroke, respiratory disease, and kidney disease were reviewed and the results were included in the final analysis of the study. NDVI was used to calculate green spaces in a 250-meter $(\mathrm{m})$ radius and 1,250-m radius around each participant's house. The residential addresses were obtained from the survey data collection. 250-m was considered directly around a participant's house and the 1,250-m distance was considered within a ten-tofifteen-minute walking distance. Both of these distances were therefore deemed appropriate to measure in order to get an accurate representation of study participants' 
surrounding green spaces. Greenness was then classified by quintiles 1 through 5 . Quintile 1 had the lowest level of green space with NDVI measuring $0.29+/-0.08$. Participants who were a part of quintile 5 lived in areas with the highest levels of green spaces with NDVI measuring $0.63+/-0.05$. These measurements correlated with the 250 $\mathrm{m}$ radius around participants' homes, results were similar for the 1,250-m radius (James et al., 2016).

The outcome of the study demonstrates that 8,604 deaths occurred between 2000 and 2008 amongst the study participants (James et al., 2016). In fully adjusted models for age, ethnicity, smoking status, parental and spousal level of education, income, marital status, and home value participants who lived in the highest quintile of greenness (quintile 5) were observed to have a $12 \%$ lower rate of all-cause mortality. These findings applied for the 250-m radius around participants' homes and were consistent with the $1,250-\mathrm{m}$ radius. Ongoing analysis also observed a $12 \%$ lower mortality rate for each 0.1 unit increase in NDVI that was consistent in the 250-m and 1,250-m radius. For cause of death specific findings, the study observed strongest associations between respiratory, cancer, and kidney disease mortality with NDVI. These causes of death had the strongest inverse relationship with NDVI. The participants who lived in highest levels of green space in the $250-\mathrm{m}$ radius around their homes had a $34 \%$ lower rate of respiratory related death, a $13 \%$ lower rate of cancer related death, and a $41 \%$ lower rate of kidney-disease related death. However, these results were not produced for participants who died from coronary heart disease related events, and no statistical significance was found between NDVI and coronary heart disease related death. This finding was inconsistent with previous studies that have shown an inverse relationship between greenness and coronary 
heart disease. However, overall results of the study suggest that green spaces have a positive impact of physiologic health and may impact overall all-cause mortality rates (James et al., 2016).

The CASP checklist for cohort studies was utilized to critically appraise this study (Appendix D1). The study fulfilled all of the applicable checklist requirements. The study clearly answered the question of whether greenness would have an impact on all-cause mortality (James et al., 2016). There were two reference standards utilized to ensure accuracy of data. The first was physician reviewed medical records and cause of death was determined using internationally accepted coding data for cause of death. NDVI was utilized to calculate green spaces around a $250-\mathrm{m}$ and $1,250-\mathrm{m}$ radius. The results of the test could not have been influenced by the reference standard because they were prospectively reviewed. The disease status is clearly described by various causes of death and then adjusted to include all-cause mortality. The methods for obtaining the data are described in great detail. Methods for both cause of death and methods for measuring green space are explained. Results of the data are presented with $95 \%$ confidence intervals. The results can be applied to a variety of patient populations since the data was collected on patients who lived across the United States in various geographical regions. The major limitation of the study is that heat and noise were unable to be measured, which could have altered the value of the green spaces (James et al., 2016). Overall, the outcomes should still be considered significant and similar studies should be performed in order to understand how green space and vegetation could have an impact on mortality. 
Yeager et al. (2018) studied if residential exposure to green space would reduce the risk of cardiovascular disease (CVD) by decreasing sympathetic nervous system (SNS) activation (Appendix C2). Four hundred eight participants ages 51.4 +/- 10.8 years took part in the study. Participants were patients from the outpatient cardiology clinic of the University of Louisville. Urine and blood samples were obtained to measure various indicators of SNS activation. Samples were collected between 1:00pm and 4:00pm EST to minimize the chance of circadian variability. Catecholamines, monoamines and their respective metabolites were measured in urine samples as an indicator of stress. The specific catecholamines measured included epinephrine, norepinephrine, dopamine, serotonin, 5-hydroxyindole-3acetic acid, homovanillic acid, and vanillylmandelic acid. Levels of F2-isoprotane were measured in urine samples as an indicator of oxidative stress. Finally, angiogenic cell measurements in the blood were obtained in order to assess the amount of circulating progenitor cells, as an indicator of the efficacy of endothelial repair. Green space was measured using NDVI. NDVI was calculated in a 250-m and 1,000-m radius around the participants' homes. NDVI was categorized as low, medium, or high. NDVI levels were considered low if they were less than 0.36, NDVI was considered medium if it ranged from 0.36-0.54 and NDVI was considered high if it was greater than 0.55 (Yeager et al., 2018).

Results of the study found that higher levels of NDVI are associated with lower levels of SNS activation and increased indicators of endothelial repair capacity (Yeager et al., 2018). Urine samples for participants in areas of high green space showed decreased levels of epinephrine as an indicator of decreased levels of stress. Each 0.1 unit increase in NDVI was associated with $6.9 \%$ lower levels of urinary epinephrine. However, 
statistical significance for the other catecholamines measured in urine was not present. Urinary measures of F2-isoprotane also inversely correlated with NDVI. Each 0.1 unit increase of NDVI caused a decrease in F2-isoprotane by $9 \%$. Levels of circulating angiogenic cells were both negatively and positively associated with NDVI levels depending on the specific angiogenic cell measured. The most significant relationship existed between the levels of CD45+/CD34+ cells. Per 0.1 unit increase in NDVI, CD45+/CD34+ cells increased by a range of $37.6 \%-45.8 \%$. Although this relationship did not exist for all angiogenic cells, the CD45+/CD34+ cells are known as being particularly robust and having superior regenerative properties to other angiogenic cells. This suggests that living in areas of higher green spaces is associated with improved wound healing. However, as the study mentions, angiogenic cells are also a component in the development of cancers, and therefore more studies would need to be conducted to more fully understand this relationship. Overall, the study found that increased levels of green space are associated with improved cardiovascular health as indicated by SNS markers in the urine and blood (Yeager et al., 2018).

The study fulfilled all of the applicable requirements in the CASP checklist (Appendix D2). It addressed a clear problem by attempting to understand if green space has an impact on SNS markers that correlate with cardiovascular disease (Yeager et al., 2018). All participants had the same urine and blood tests drawn during the same time frame and NDVI was used to measure green space around every participant's residential address. The participants had preexisting CVD or were at risk for CVD. Methods and results were described in detail. Results are presented with $95 \%$ confidence intervals. The study has some limitations including the lack of estimating specific environmental 
exposures such as roadways that alter greenness. Similar to James et al. (2016), the study also did not take in to account psychosocial greenness, personal health behaviors or heat regulation. Finally, although the study could be relevant to a population at risk for CVD, it may not be relevant to a healthy population (Yeager et al., 2018). However, the impact of using this study on a general population of acute care patients would allow patients to be able to understand that their risk factors for developing CVD could correlate with levels of green spaces around their residence.

Pereira, Foster, et al. (2012) studied if neighborhood greenness was associated with decreased self-reported diagnosis of or hospitalization for coronary heart disease or stroke (Appendix C3). This cross-sectional study was conducted with 11,404 adults. Participants were age 25 years or older who were residents of the Perth metropolitan area in Western Australia. Participants answered survey questions from the Western Australian Health and Wellbeing Survey, a monthly, computer-assisted survey, between 2003 and 2009. Survey responses were reviewed for self-report of medically diagnosed coronary heart disease or stroke. Additionally, hospital records were obtained from the Australian Department of Health to assess for participants' history of hospitalization related to coronary heart disease or stroke. Green spaces were calculated using NDVI. Neighborhood greenness was measured in a 1600-m radius around the participants' homes. The rationale for choosing this distance was that it was considered within walking distance of each participant's residence. Green spaces ranged from a low NDVI of -0.059 to a high NDVI of 0.337 . NDVI ranges for this study were low compared to other studies since the participants lived in a mostly urban setting. The study notes that the type of vegetation in high NDVI regions was bush land and located on the urban-rural fringe of 
the city. The lowest level of NDVI was present in neighborhoods with primarily commercial and industrial land. Variation in green spaces was also observed. Areas with high green space variability contain both high NDVI and low NDVI within the $1,600-\mathrm{m}$ area. Standard deviation of NDVI was calculated to find the areas of high and low green space variability among study participants. The area with the highest variability in green space had a NDVI standard deviation of 0.205 and the areas of lowest variability were calculated as 0.048 (Pereira, Foster, et al., 2012).

The study found that a total of 367 of the participants had been hospitalized for coronary heart disease or stroke during the duration of the study (Pereira, Foster, et al., 2012). An additional 1,415 participants had reported a diagnosis of heart disease. After full adjustment for socio-demographic factors of age, sex, possession of a healthcare card, education, income, biologic factors such as diabetes, hypertension, hypercholesterolemia, body mass index (BMI), and behavioral factors such as dietary habits, smoking and alcohol use, the study did not find any statistically significant evidence to support higher green spaces can lead to decreased coronary heart disease or stroke. Significant findings were found for variability in greenness and rates of disease. Participants in areas with moderate levels of variability had a 16\% lower chance of selfreporting heart disease or stroke as opposed to participants living in areas of low variability. Furthermore, rates of hospitalization in areas of high variability were $37 \%$ lower than in areas of low variability (Pereira, Foster, et al., 2012).

The CASP checklist was utilized to evaluate the study's integrity (Appendix D3). All applicable requirements in the checklist were fulfilled. The study addressed a clear question of the impact of green spaces on coronary heart disease or stroke diagnosis 
and/or hospitalization (Pereira, Foster, et al., 2012). All participants received the reference standard and were screened for history of disease or hospitalization. Neighborhood green space was measured using NDVI. Results could not have been influenced by the standard since a standardized measurement was used. Disease status of a diagnosis or hospitalization of coronary heart disease or stroke is clearly identified. Methods were reported in detail and results were reported with $95 \%$ confidence intervals. The results could be easily applied to acute care adult patients due to the variability of participants in the cohort that was studied. The outcomes of the study are significant to this and other acute care adult populations as they suggest further understanding of risk factors in developing heart disease or stroke. The major limitation of this study is the lack of adjusting for physical activity rates, which would independently impact cardiovascular health (Pereira, Foster, et al., 2012).

Pereira, Christian, et al. (2013) conducted a study utilizing a similar cohort of participants from the Western Australian Health and Wellbeing Survey to assess the impact that green spaces have on weight status (Appendix C4). There were 10,208 participants that participated in the cross-sectional study. Participants completed the survey between the years of 2004 and 2009 and were grouped based on age as young adult (16-24 years old), middle age adults (25-64 years old), and older adults ( $>65$ years old). The distribution of the age of participants in the study included 1,073 young adults, 6,328 middle age adults, and 2,897 older adults. Self-reported height and weight were obtained in order to calculate body mass index (BMI). Participants were considered obese if their BMI was greater than 30 and they were considered overweight/obese if their BMI was greater than 25. Green spaces were measured using NDVI. NDVI was calculated for 
a $1,600 \mathrm{~m}$ radius around each participant's home address obtained through the survey database. Variability in green space was also calculated by assessing standard deviation of green space in the participants' residential areas. Mean greenness ranged from -0.059 to a high of 0.337 and variation in greenness ranged from 0.048 to 0.205 (Pereira, Christian, et al., 2013).

Results of the study found that $19 \%$ of the total test population was classified as obese and 53\% were identified as overweight/obese (Pereira, Christian, et al., 2013). After full adjustment for age, sex, education, diet, and smoking status, the study found that the odds for being overweight/obese was lower $(0.84 ; 95 \%$ CI: $0.76-0.92)$ for adults in areas with high levels of mean green space as compared to those with low levels of green space by $16 \%$. The results were similar for participants in high versus low areas of variability in green space $(0.75 ; 95 \%$ CI: $0.68-0.82)$ by $25 \%$. Both of these finding were considered statistically significant. The findings for obese participants were similar and there was $22 \%$ less chance of reporting obesity in areas with high mean green spaces and $25 \%$ less chance of reporting obesity in areas of high variability in greenness with corresponding data results of $(0.78 ; 95 \%$ CI: $0.69-0.89)$ and $(0.75 ; 95 \%$ CI: $0.66-0.85)$ respectively (Pereira, Christian, et al., 2013).

CASP was utilized to assess the integrity of this study (Appendix D4). The study fulfilled all of the applicable checklist requirements. A clear question about the relationship between green spaces and weight status was studied (Pereira, Christian, et al., 2013). All participants received the reference standard of calculated BMI for weight status and NDVI for levels of greenness. The disease status is clearly stated as obese with a BMI of greater than 30 or overweight-obese with a BMI greater than 25 . The methods 
and results of the test were described in sufficient detail. Results were presented with 95\% confidence intervals (Pereira, Christian, et al., 2013). Limitations in this study are similar to the study by Pereira, Foster, et al. (2012) since the results are not adjusted for physical activity, and although adjustments were made for level of education, adjustments made for current socioeconomic status were lacking (Pereira, Christian, et al., 2013). The results could easily be applied to any population of acute care adult patients in order to understand an additional risk factor for development of obesity.

Huang et al. (2019) also performed a cross-sectional study investigating the relationship between weight status and green spaces (Appendix C5). Participants in this study were selected from the cohort that participated in the 33 Communities Chinese Health Study in 2009. This study is a large-scale population study that is conducted in the Liaoning province, Northeast China. Due to the rapid urbanization of the region, this region is considered at risk for increasing levels of obesity. A random number generator selected the participants. Three provinces in the area were selected and then three communities within that province were randomly selected as well. 700 to 1000 study households were then randomly selected and then one adult greater than 17 years old was randomly selected to take place in the study. This yielded 24,845 study participants. Height, weight and waist circumference were recorded from each of the study participants during a physical exam. BMI was then calculated and peripheral obesity was defined as a BMI greater than 30 and central obesity was defined as a waist circumference (WC) greater than $102 \mathrm{~cm}$ in males and $88 \mathrm{~cm}$ in females. NDVI was calculated in each participant's community. A 500-m radius was used as the primary 
measure for the study and a 1000-m measurement was used to assess ongoing sensitivity. NDVI values ranged from a low of 0.18 to a high of 0.80 (Huang et al., 2019).

Results of the study found a mean BMI of $24.40 \mathrm{~kg} / \mathrm{m} 2$ and a mean $\mathrm{WC}$ of 83.24 $\mathrm{cm}$ with gender differences showing an average of $86.16 \mathrm{~cm}$ in men and $80.18 \mathrm{~cm}$ in women (Huang et al., 2019). An inverse relationship existed between NDVI values and BMI. The same relationship existed between NDVI and WC. Data found that for each 0.17 unit increase in NDVI in the 500-m radius, BMI decreased by $0.18 \mathrm{~kg} / \mathrm{m} 2$, with $20 \%$ lower odds for peripheral obesity and $12 \%$ lower odds for central obesity. These results were considered statistically significant. Results were similar for the 1,000-m radius around participants' communities. The study also assessed the impact that age had on the outcomes and found that there was a stronger association for NDVI at the 500-m radius and rates of peripheral and central obesity among the older participants as compared to the younger participants. Overall, results of the study found that green space is inversely associated with weight status (Huang et al., 2019).

The study fulfilled all applicable requirements in the CASP checklist (Appendix D5). The study addressed a clear question about the effect of green space on levels of central and peripheral obesity in adults (Huang et al., 2019). All adults received the reference standard of height, weight, WC measurements, and calculated BMI. Furthermore, all participants had greenness calculated using NDVI in a 500-m and 1,000$m$ radius around their homes. Disease status is clearly stated as presence of peripheral or central obesity. Methods and results for the study are described in sufficient detail. Results are reported with $95 \%$ confidence intervals. The results of this test can be applied to any population of acute adult care patients and further prove that exposure to green 
space can have protective physiologic health benefits. One of the major limitations of the study is that it does not address the impact that physical activity could have on weight status. Data adjustment did not include rates of physical activity therefore it is unknown if participants who live in higher areas of green spaces are also more active physically. Further testing would need to be conducted in order to understand this relationship more fully. Additionally, NDVI calculations are conducted in a radius covering participant's community centers and not their individual residences. This could have an impact as well since some participants may live further away from the community center and the greenness in their direct residential environment may differ from that at the community centroid. Overall, the study did conclude that increased levels of green spaces have shown to decrease likeliness of residents having central or peripheral obesity (Huang et al., 2019).

Yang et al. (2018) also utilized the 33 Communities Chinese Health Study to understand the relationship between green spaces and rates of diabetes and glucose homeostasis markers that can lead to the development of diabetes mellitus in a crosssectional study (Appendix C6). Of the 28,845 participants who took place in the 33 Communities Chinese Health Study, 15,477 agreed to provide a blood sample and were therefore included in the final analysis of the study. Study participants fasted for 12 hours overnight and then underwent a standard 75-g oral glucose tolerance test. Blood samples were drawn at zero and two hours after glucose intake. Fasting and two-hour glucose and insulin levels were determined based on the blood samples. Insulin resistance was also calculated and beta cell function was also measured. Diabetes was defined using the American Diabetes Association standard as a fasting glucose greater than $7.0 \mathrm{mmol} / \mathrm{L}$, a 
two-hour glucose of greater than $11 / 1 \mathrm{mmol} / \mathrm{L}$, or any use of an anti-diabetic medication by the study participant. Green space was measured at a 100-m, 500-m, and 1,000-m radius around each participant's community center using NDVI. The 500-m radius was the only distance used in the final analysis of the paper (Yang et al., 2018).

Results found that the mean age of the participants was 45 years old. NDVI ranged from a low of 0.18 to a high of 0.80 . A total of 1,694 participants were positive for diabetes mellitus (Yang et al., 2018). Data collection found that an inverse relationship between NDVI and diabetes mellitus prevalence, fasting glucose, two-hour glucose, two-hour insulin and insulin resistance existed. Specifically, for each 0.1 unit increase in NDVI, prevalence of diabetes mellitus decreased $12 \%$. Similarly, fasting glucose levels decreased 1.14\%, two-hour glucose decreased 2.03\%, two-hour insulin decreased $1.66 \%$, and insulin resistance decreased by $1.17 \%$. Beta-cell function increased as NDVI increased with $3.33 \%$ higher beta cell function recorded per each 0.1 unit increase in NDVI. These results suggest that increased green space may be associated with improved beta cell health and result in decreased prevalence of diabetes mellitus and the homeostasis markers that can lead to the development of diabetes mellitus (Yang et al., 2018).

This study fulfilled all of the applicable requirements outlined in the CASP checklist (Appendix D6). A clear study question about the impact of green spaces on rates of diabetes mellitus and glucose markers that can lead to the development of diabetes mellitus was addressed (Yang et al., 2018). All participants had the same reference standard and were assessed for glucose, insulin, and beta cell function levels after undergoing an oral glucose tolerance test. NDVI was also calculated around the 
participants' community centers. This part of the study does also pose as a limitation since some participants may not have lived, or spent as much time near the community center as others and therefore it would not be a completely accurate representation of residential green space (Yang et al., 2018). The disease status is clearly listed as having diabetes mellitus based on the American Diabetic Association classifications for diabetes mellitus. Methods and results were described in sufficient detail. Results are reported with $95 \%$ confidence intervals. Results of the study are significant and can be applied to a variety of acute care adult patients. The outcome of the study suggests that it should be recognized that lack of green spaces could predispose an individual to the development of diabetes mellitus.

\section{Cross-Study Analysis}

A cross study analysis of the articles included in this study was conducted (Appendix E). The analysis observed green space levels as calculated by NDVI in each individual study and overall physiologic outcomes as they relate to green space.

Outcomes were listed as positive, meaning that green space had a protective effect on health or improved health outcomes, or negative, meaning green space posed a detriment to health, or no impact at all. Furthermore, inconsistencies in data reporting were noted.

All cohort studies included in this review assessed a physiologic outcome as it compared to levels of green space. All studies utilized NDVI to measure green spaces. Specific physiologic outcome of each study was described in detail. The relationship between green space and physiologic outcome was identified as an inverse or direct relationship. All statistically significant physiologic outcomes were considered good, positive outcomes. 
NDVI measurements varied between each study based on the land coverage distance that each study measured, however each study had similar rationales for the distance that was chosen. Huang et al. (2019) and Yang et al. (2018) utilized a 500-m radius around each participant's community centroid. This distance was considered appropriate because it was considered to represent a mean greenness of each participant's community (Huang et al., 2019). Green space distances in all other studies were measured immediately outside each residential address, or within a ten-to-fifteen-minute walking distance and was therefore considered an accurate representation of each participant's surrounding green space (James et al., 2016, Pereira, Foster, et al. 2012, and Pereira, Christian, et al. 2013). Pereira, Foster et al. (2012) and Pereira, Christian, et al. (2013) found significant relationships between variability of green spaces and physiologic outcomes. Nonetheless, data collection for the relationship between mean greenness and physiologic outcomes was still obtained in those studies.

Each study included in this review demonstrated that increased exposure to green spaces is associated with positive health outcomes. The results were only statistically significant when viewing green space variability for Pereira, Foster, et al. (2012) and Pereira, Christian, et al. (2013). Results from James et al. (2016) showed decreased rates of all-cause mortality in areas with increased green spaces. Rates of cardiovascular related illness was decreased in areas of higher green space and green space variability as evidenced by Yeager et al. (2018) and Pereira, Foster, et al. (2012). Rates of obesity were less in areas of higher green space as evidenced by Huang et al. (2019) and Pereira, Christian, et al. (2013). Finally, Yang et al. (2018) showed incidence of diabetes was decreased in areas with higher green spaces. 
Next, the summary and conclusion will be discussed. 


\section{Summary and Conclusions}

Understanding the impact that green space has on physiologic health is a simple, yet overlooked aspect to providing holistic care to the adult patient. Green spaces have been identified as necessary components to city developments in order to promote healthy habits and improve air quality (Russo \& Cirella, 2018). A literature review was conducted to verify the impact that green spaces have on physical health. Brown et al. (2013) found that heart rate variability was increased amongst participants who were shown views of nature after a stressor had been introduced to their environment as opposed to those who were not shown views of nature after the stressor was introduced. Increased heart rate variability is associated with improved health due to the ability of the autonomic nervous system to rebound from stress. Twohig-Bennet and Jones (2018) conducted a systematic review and found that cardiovascular disease mortality and rates of diabetes were less in areas of higher levels of green spaces. These studies represent a sample of the studies conducted on green spaces and physical health benefits, however they all use various forms of measurement for green space and consistency of the effects is not well reported. This supported the intent to conduct a systematic review to determine the impact that green spaces measured using NDVI have on physical health in terms of mortality, cardiovascular health, obesity, and diabetes.

The purpose of this systematic review was to understand the effect that green spaces can have on physiologic health. CINHAL, PubMed, and Google Scholar were utilized to find appropriate research articles. PRISMA checklist and flow diagram was completed to show the method for obtaining and narrowing the articles. Inclusion and exclusion criteria were identified and a total of six studies were chosen to be included in 
the final review. Each study was assessed for integrity using the CASP checklist for cohort studies. Data tables were created and study data was extracted and reviewed in great detail. Cross-study analysis took place at the end of the data collection and focused on the health outcomes as either positive or negative as green spaces increased. Health outcomes were considered positive if they were associated with better physical health and were considered negative if outcomes were associated with poor physical health.

All six studies in this systematic review utilized NDVI as a measurement for green spaces. Results of physical health outcomes were presented in percentages per unit increase in NDVI or as NDVI increased from low to moderate to high levels. All studies found that indicators of poor physical health and green spaces had an inverse relationship, meaning health outcomes were better (positive) as NDVI increased. Some limitations to this review included the inconsistencies in how each individual study adjusted the data. Every study did not adjust data for participants' levels of physical activity. This could mean that participants who lived in areas of more dense green space were more physically active. Therefore results for improved physical health could be linked to levels of physical activity rather than green space independently. Furthermore, the radius that measured green spaces varied in each study. Some studies measured green spaces around personal residences and others measured green spaces around the cohorts' community centers. One final limitation is that the studies by Pereira, Foster, et al. (2012) and Pereira, Christian, et al. (2013) only noticed statistically significant health benefits when observing green space variation. Benefits were noted when looking at mean green space, but they were not reported as statistically significant. This suggests that there may have been a physical activity component to the results. 
In summary, the six studies that were analyzed in this systematic review support the hypothesis that increasing levels of green spaces lead to improved physical health outcomes.

Next, the recommendations and implications for advanced nursing practice will be discussed. 


\section{Recommendations and Implications for Advanced Nursing Practice}

A holistic picture of an acute care patient is crucial to provide high quality care and an appropriate care plan. Florence Nightingale, known as the founder of modern nursing, recognized the need for all patients to have access to light, fresh air, adequate temperature, and clean spaces in order to heal. However, the general benefits of green spaces on health frequently focus on the psychological end of the spectrum, not the physical. As years have passed, physiologic health benefits of green space are rarely discussed and even more rarely considered in nursing. Many studies have discussed the impact of green spaces on physical health, but consistency between studies is limited.

This systematic review sought a clearer understanding of effect of green space on the physiologic function of the adult, and answered the question: if green space increases, does physical health improve. The final results of this review support the claim that physical health is better for those who live in areas with more green spaces as defined by NDVI. In the instance of this review for example, low levels of residential green spaces correlated with higher levels of obesity, cardiovascular illness, diabetes, and all-cause mortality. This is a meaningful finding when it comes to the care of the adult patient. Green spaces, or lack thereof, are not currently considered as a part of the patient's physical health assessment screening. However, as this review demonstrates, green spaces can have a protective effect on physiologic health and should therefore be considered when inquiring about a patient's lifestyle in order to fully understand the patient's risk factors. Nurses, including the advanced practice nurse, are responsible for understanding modifiable and non-modifiable risk factors and educating their patients about these factors so that patients can make informed health decisions. 
The development of educational plans, which include changes in practice for nurses, is an essential part of the advanced practice nurse's role. The advanced practice nurse would need to be a pioneer in educating nurses about the importance of understanding a patient's physical surrounding as a risk factor for health issues. The clinical nurse specialist is an advanced practice nurse who plays a pivotal role in providing education to practicing nurses. Furthermore, the CNS utilizes the synergy model to guide practice. This model has three spheres: patient, nurse, and system. The clinical nurse specialist continually strives to understand the three spheres and improve nursing practice by focusing on how the three spheres interact. By accepting physical environment as a risk factor for health outcomes, the CNS plays an influential role in normalizing this knowledge as a common determinant for health. In providing education to the nurses and patients about this risk factor, the CNS would work in the nurse and patient sphere of the synergy model. Subsequently, systems level of thinking is affected due to this new change in practice to include lack of green space as a potential risk factor for the development of illness. By role modeling an acceptance of levels of green space as a determinant for health, the clinical nurse specialist will promote ongoing understanding of the dynamic risk factors that determine health outcomes. 


\section{References}

Altaweel, M. (2017, July 14). Measuring vegetation from satellite imagery with NDVI. GIS Lounge. https://www.gislounge.com/measuring-vegetation-satellite-imageryndvi/

Brown, D.K, Baron, J.L, Gladwell, V.F. (2013). Viewing nature scenes positively affects the recovery of autonomic function following acute-mental stress. Environmental Science and Technology. 5562-5569. http://doi.org/10.1021/es305019p.

den Braver, N., Lakerveld, J., Schoonmade, L., Brug, J., \& Beulens, J. (2018). Built environmental characteristics and diabetes: a systematic review and metaanalysis. Diabetes: Prevention, Management and Treatment.

http://doi.org/10.1186/s12916-017-0997-z

Generalized land use database statistics for England 2005. (2007, February). Department for Communities and Local Government. https://assets.publishing.service.gov.uk/government/uploads/system/uploads/attac hment_data/file/825473/GLUD_Statistics_for_England_2005.pdf

Hegge, M. (2013). Nightingale's environmental theory. Nursing Science Quarterly, 26(3), 211-219. http://doi.org/10.1177/0894318413489255

Huang, W., Yang, B., Yu, H., Bloom, M.S., Markevych, I., Heinrich, J., Knibbs, L,D., Leskinen, A., Dharmage, S.C., Jalaludin, B., Morawska, L., Jalava, P., Guo, Y., Lin, S., Zhou, Y., Liu, R., Feng, D., Hu, L., Zeng, X...Dong, G. (2019). Association between community greenness and obesity in urban-dwelling Chinese adults. Science of the Total Environment 702 (2020).

http://doi.org/10.1016/j.scitotenv.2019.125040. 
James, P., Hart, J. E., Banay, R. F., Laden, F. (2016). Exposure to greenness and mortality in a nationwide prospective cohort study of women. Environmental Health Perspectives, 124 (9), 1344-1352. http://doi.10.1289/ehp.1510363.

Kamau, S. M., Rotich, R. J., Cheruiyot, B. C., \& Ng'eno, L. C. (2015, August 26). Applying Florence Nightingale's model of nursing and the environment on multiple drug resistant tuberculosis infected patients in the Kenyan setting. Open Access Library Journal, 2, 1-10. http://doi.org/10.4236/oalib.1101796

Land Cover Map for 2015. (n.d.) UK Center for Ecology and Hydrology. https://www.ceh.ac.uk/services/land-cover-map-2015\#data

Maas, J. (2008). Vitamin G: Green environments-Healthy environments. Nivel.

McCorry, L.K. (2007, August 15). Physiology of the autonomic nervous system. American Journal of Pharmaceutical Education. 71(4). 1-11. https://www.ncbi.nlm.nih.gov/pmc/articles/PMC1959222/pdf/ajpe78.pdf

Measuring Vegetation (NDVI \& EVI). (2000). https://earthobservatory. nasa.gov/ features/MeasuringVegetation/measuring_vegetation_2.php Moher, D., Liberati, A., Tetzlaff, J., \& Altman, D. G. (2009, August 18). Preferred reporting items for systematic reviews and meta-analyses: the PRISMA statement. Annals of Internal Medicine, 151(4), 264-269. http://annals.org

Nightingale, Florence, 1820-1910. (2010). Notes on nursing: what it is, and what it is not. New York: Dover Publications.

Ord, K., Mitchell, R., Pearce, J. (2013). Is level of neighborhood green space associated with physical activity in green space? International Journal of Behavioral Nutrition and Physical Activity. http://doi:10.1186/1479-5868-10-127 
Pereira, G., Christian, H., Foster, S., Boruff, B. J., Knuiman, M., Giles-Corti, B. (2013, June 9). The association between neighborhood greenness and weight status: An observational study in Perth Western Australia. Environmental Health, 12(29). http://doi:10.1186/1476-069X-12-49.

Pereira, G., Foster, S., Martin, K., Christian, H., Boruff, B. J., Knuiman, M., \& GilesCorti, B. (2012). The association between neighborhood greenness and cardiovascular disease: an observational study. BMC Public Health 12(466). http://doi.org/10.1186/1417-2458-12-466

Raanaas, R. K., Patil, G., \& Alve, G. (2016). Patients' recovery experiences of indoor plants and views of nature in a rehabilitation center. Work, 53, 45-55. http://doi.org/10.3233/WOR152214

Raanaas, R. K., Patil, G. G., \& Hartig, T. (2011). Health benefits of a view of nature through the window: a quasi-experimental study of patients in a residential rehabilitation center. Clinical Rehabilitation, 24(1), 21-32.

http://doi.org/10.1177/0269215511412800

Russo, A, Cirella, G.T. (2018). Modern compact cities: How much greenery do we need? International Journal of Environmental Research and Public Health. 1-15. http://doi:10.3390/ijerph15102180

Taylor, L., Hochuli, D.F. (2017). Defining greenspace: Multiple uses across multiple disciplines. Landscape and Urban Planning. 25-38. http://doi.org/10.1016/j.landurbplan.2016.09.025

Twohig-Bennett, C., \& Jones, A. (2018, February 25). The health benefits of the great 
outdoors: A systematic review and meta-analysis of greenspace exposure and health outcomes. Environmental Research, 628-637.

http://doi.org/10.1016/j.enveres. 2018.06.030

White, M., Alcock, I., Grellier, J., Wheeler, B., Hartig, T., Warber, S., Bone, A., Depledge, M., Fleming, L. (2019). Spending at least 120 minutes a week in nature is associated with good health and wellbeing. Scientific Reports, 9(7730). http://doi:org/10.1038/s49518-019-44097-3.

Yang, B., Markevych, I., Heinrich, J., Bowatte, G., Bloom, M.S., Guo, Y., Dharmage, S.C., Jalaludin, B., Knibbs, L.D., Morawska, L., Qian, Z., Chen, D., Ma, H., Chen, D., Lin, S., Yan, M., Liu, K., Zeng, X., Hu, 1., Dong, G. (2018, December 2). Associations of greenness with diabetes mellitus and glucose-homeostasis markers: The 33 Communities Chinese Health Study. International Journal of Hygiene and Environmental Health, 222 (2019), 283-290. http://doi.org/10.1016/j.ijheh.2018.12.001.

Yeager, R., Riggs, D., DeJarnett, N., Tollerud, D.J., Wilson, J., Conklin, D.J., O’Toole, T.E., McCracken, J., Lorkiewicz, P., Xie, Z., Zafar, N., Krishnasamy, S.S., Srivastava, S., Finch, J., Keith, R.J., DeFilippis, A., Rai, S.N., Liu, G., Bhatnagar, A. (2018). Association between residential greenness and cardiovascular disease risk. Journal of the American Heart Association.

http://doi:10.1161/JAHA.118.009117. 


\section{Appendix A}

\section{PRISMA 2009 Flow Diagram}

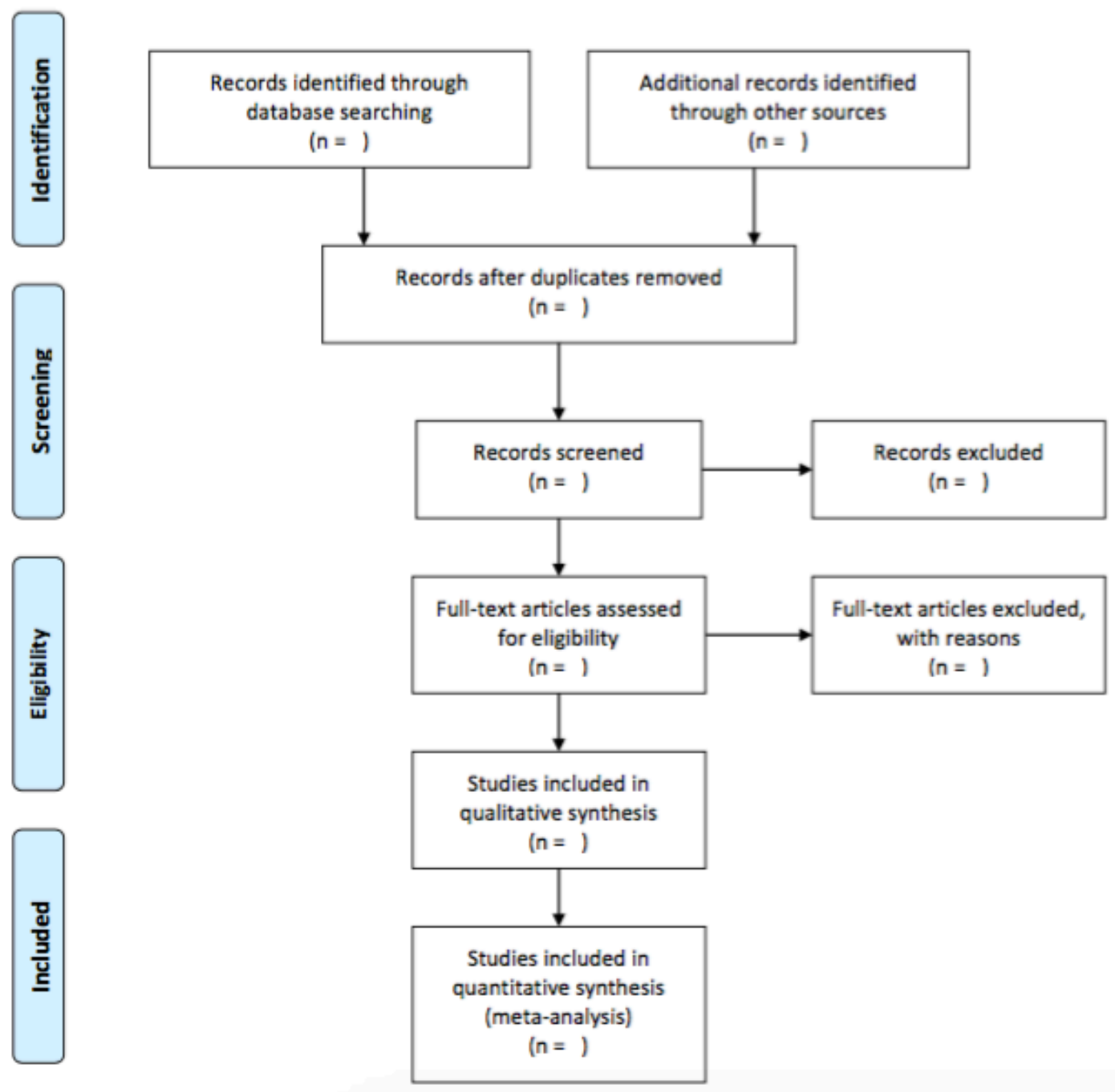

(Moher et al., 2009) 


\section{Appendix B}

\section{PRISMA 2009 Checklist}

\begin{tabular}{|c|c|c|c|}
\hline Sectionitopic & \# & Checkllat Item & $\begin{array}{l}\text { Reportad } \\
\text { on page } *\end{array}$ \\
\hline \multicolumn{4}{|l|}{ TITLE } \\
\hline Title & 1 & Itentify the report as a systematic review, meta-analysis, or both. & \\
\hline \multicolumn{4}{|l|}{ ABSTRACT } \\
\hline Structured summary & 2 & $\begin{array}{l}\text { Provide a struclured summary including, as applicable: background, otjectives; data sources; study eligibility eritera, } \\
\text { participants, and interventions; study appraisal ard synthesis metheds; results; Imilations; concluasions and } \\
\text { implicatons of key findings; systematic review registration number. }\end{array}$ & \\
\hline \multicolumn{4}{|l|}{ INTRODUCTION } \\
\hline Rationale & 3 & Describe the ratonale for the review in the context of what is already known. & \\
\hline Objectives & 4 & $\begin{array}{l}\text { Provide an explicit statement of questions being addressed with reference to participants, interventons, comparisons, } \\
\text { outcomes, and study design (PICOS). }\end{array}$ & \\
\hline \multicolumn{4}{|l|}{ METHODS } \\
\hline Protocol and registration & 5 & $\begin{array}{l}\text { Indicate if a review protocol exists, if and where it can be accessed (e.g. Web adcress), and, if avallable, provice } \\
\text { registration information including registration number. }\end{array}$ & \\
\hline Eligbiilty criteria & 6 & $\begin{array}{l}\text { Specify study characteristics (e.g., PICOS, length of follow up) and repert characteristics (e.g., years considered, } \\
\text { language, publication status) used as criteria for eligibility, giving rationale. }\end{array}$ & \\
\hline Information sources & 7 & $\begin{array}{l}\text { Deseribe all information sources (e.g, databases with dates of coverage, eontact wth study authors to identify } \\
\text { atditional studies) in the search and date last searched. }\end{array}$ & \\
\hline Search & 8 & $\begin{array}{l}\text { Present full electronic search strategy for at least one database, including any imits used, such that it could be } \\
\text { repeated. }\end{array}$ & \\
\hline Study selecton & 9 & $\begin{array}{l}\text { State the process for selecting stuties (i.e., screening, eligibility, induded in systematic review, and, if applicatie, } \\
\text { incluted in the meta analysis). }\end{array}$ & \\
\hline Data collection process & 10 & $\begin{array}{l}\text { Describe method of data extraction from reports (e.g, pilated forms, independently, in duplicate) and any processes } \\
\text { for obtaining and confiming data from investigators. }\end{array}$ & \\
\hline Data items & 11 & $\begin{array}{l}\text { List and define all variables for which data were sought (e.g. PICOS, funding sources) and any assumptions and } \\
\text { simplifications made. }\end{array}$ & \\
\hline $\begin{array}{l}\text { Risk of bias in intivitual } \\
\text { stucies }\end{array}$ & 12 & $\begin{array}{l}\text { Deseribe methods used for assessing risk of bias of indivitual studies (incluting specification of whether this was } \\
\text { done at the study or cutecme level), and how this infermatien is to be used in any data synthesis. }\end{array}$ & \\
\hline Summary measures & 13 & State the principal summary measures (e.g., risk ratio, difference in means). & \\
\hline Synthesis of results & 14 & $\begin{array}{l}\text { Deseribe the metheds of handling data and combining results of stuclies, if done, including measures of consistency } \\
\text { (e.g., } 1^{2} \text {; for each meta analysis. }\end{array}$ & \\
\hline Risk of bias across studies & 15 & $\begin{array}{l}\text { Specify ary assessment of risk of bias that may affect the cumulative evidence (e g. publication bias, seiective } \\
\text { reperting within stucties). }\end{array}$ & \\
\hline Additional anaiyses & 16 & $\begin{array}{l}\text { Describe methods of additional analyses (e.9., sensitivity or subgroup analyses, meta-regression), if done, indicating } \\
\text { which were pre-specified. }\end{array}$ & \\
\hline \multicolumn{4}{|l|}{ RESULTS } \\
\hline Study selecton & 17 & $\begin{array}{l}\text { Give numbers of studies screened, assessed for eigblity, and included in the review, with reasons for exelusicns at } \\
\text { each stage, idealy with a fow diagram. }\end{array}$ & \\
\hline Study characteristics & 18 & $\begin{array}{l}\text { For each study, present eharacteristics for which data were extracted (e.g. stucty size, PICOS, folow-up period) and } \\
\text { provide the citations. }\end{array}$ & \\
\hline Risk of bias within studies & 19 & Present data on risk of blas of each study and, If avalable, any outcome level assessment (see item 12). & \\
\hline Results of incivitual studies & 20 & $\begin{array}{l}\text { For all outecmes considered (benefits or harms), present, for each study: (a) simple summary data for each } \\
\text { intervention group (b) effect estimates and confidence intervals, idealy with a forest plot. }\end{array}$ & \\
\hline Synthesis of results & 21 & Present resuts of each meta-analysis done, including conficence intervais and measures of consistency. & \\
\hline Risk of bias across studies & 22 & Present results of any assessment of risk of bias acruss studies (see ltem 15). & \\
\hline Adeitional analysis & 23 & Give results of additional analyses, if done (e.g. sensitivity or subgroup ana)yses, meta-regression (see ltem 16]). & \\
\hline \multicolumn{4}{|l|}{ DISCUSSION } \\
\hline Summary of evidence & 24 & $\begin{array}{l}\text { Summarze the main findings including the strength of evidence for each main outcome; consider their relevance to } \\
\text { key groups (e.g. healthcare providers, users, and policy makers). }\end{array}$ & \\
\hline Limitations & 25 & $\begin{array}{l}\text { Discuss limitations at study and outcome level (e.g. risk of bias), and at review-level (e.g. incomplete retrieval of } \\
\text { identified research, reporting bias). }\end{array}$ & \\
\hline Conclusiens & 26 & Provide a general interpretaton of the results in the context of other evidence, and implicasons for future research. & \\
\hline \multicolumn{4}{|l|}{ FUNDING } \\
\hline Funding & 27 & $\begin{array}{l}\text { Describe sources of funding for the systematic review and other support (e.9. supply of data); role of funders for the } \\
\text { systematic review. }\end{array}$ & \\
\hline
\end{tabular}

(Moher et al., 2009) 
Appendix C

Data Collection Tables

\begin{tabular}{|c|c|c|c|c|c|}
\hline \multicolumn{6}{|c|}{ Title } \\
\hline Purpose & Population & Demographic & Methods & NDVI Range & $\begin{array}{l}\text { Physiologic } \\
\text { Outcome }\end{array}$ \\
\hline & & & & & \\
\hline & & & & & \\
\hline & & & & & \\
\hline & & & & & \\
\hline & & & & & \\
\hline & & & & & \\
\hline & & & & & \\
\hline & & & & & \\
\hline & & & & & \\
\hline & & & & & \\
\hline & & & & & \\
\hline
\end{tabular}


Table C1-

\begin{tabular}{|c|c|c|c|c|c|}
\hline \multicolumn{6}{|c|}{$\begin{array}{l}\text { James, P., Hart, J. E., Banay, R. F., Laden, F. (2016). Exposure to greenness and mortality in a } \\
\text { nationwide prospective cohort study of women. Environmental Health Perspectives, } 124 \text { (9), 1344-1352. } \\
\text { http://doi.10.1289/ehp.1510363. }\end{array}$} \\
\hline Purpose & Population & Demographic & Methods & NDVI Range & $\begin{array}{l}\text { Physiologic } \\
\text { Outcome }\end{array}$ \\
\hline $\begin{array}{l}\text { Discover if higher } \\
\text { levels of } \\
\text { surrounding } \\
\text { residential } \\
\text { greenness led to } \\
\text { lower rates of all- } \\
\text { cause cancer, } \\
\text { respiratory, and } \\
\text { cardiovascular } \\
\text { mortality. }\end{array}$ & $\begin{array}{l}108,630 \\
\text { participants from } \\
\text { the Nurses' Health } \\
\text { Study enrolled in } \\
\text { the study. The } \\
\text { Nurses' Health } \\
\text { Study cohort } \\
\text { assesses risk } \\
\text { factors for chronic } \\
\text { disease in women. }\end{array}$ & $\begin{array}{l}\text { The all-female } \\
\text { cohort were ages } \\
30-55 \text { years old } \\
\text { when the Nurses' } \\
\text { Health Study } \\
\text { began in } 1976 . \text { The } \\
\text { women had a } \\
\text { variety of health- } \\
\text { related exposures } \\
\text { and medical } \\
\text { diagnoses. All } \\
\text { women live in the } \\
\text { United States. }\end{array}$ & $\begin{array}{l}\text { Participants in the } \\
\text { study were } \\
\text { followed between } \\
\text { the years of } 1997 \\
\text { and } 2008 \text {. } \\
\text { Participants were } \\
\text { sent a biennial } \\
\text { survey to } \\
\text { complete. }>90 \% \text { of } \\
\text { surveys were } \\
\text { consistently } \\
\text { completed } \\
\text { throughout the } \\
\text { study. Deaths that } \\
\text { occurred between } \\
\text { 2000 and } 2008 \\
\text { were assessed for } \\
\text { primary cause of } \\
\text { death. Residential } \\
\text { addresses were } \\
\text { obtained from the } \\
\text { expired } \\
\text { participants. NDVI } \\
\text { was calculated } \\
\text { using satellite } \\
\text { imagery. }\end{array}$ & $\begin{array}{l}\text { NDVI ranged from } \\
\text { a low of } 0.29+/- \\
0.08 \text { to a high of } \\
0.62+/-0.05 \text {. } \\
\text { NDVI was } \\
\text { calculated at a } \\
250-m \text { and } 1,250- \\
\text { m radius around } \\
\text { the participants' } \\
\text { home. }\end{array}$ & $\begin{array}{l}\text { Results of the } \\
\text { study show a } 12 \% \\
\text { lower all-cause } \\
\text { mortality rate in } \\
\text { those living in the } \\
\text { highest areas of } \\
\text { greenness within a } \\
250 \text {-m radius } \\
\text { around their } \\
\text { homes. The results } \\
\text { are similar but less } \\
\text { consistent for the } \\
1,250-m \text { radius } \\
\text { surrounding the } \\
\text { participants' } \\
\text { homes. }\end{array}$ \\
\hline
\end{tabular}


Table C2-

\begin{tabular}{|c|c|c|c|c|c|}
\hline \multicolumn{6}{|c|}{$\begin{array}{l}\text { Yeager, R., Riggs, D., DeJarnett, N., Tollerud, D.J., Wilson, J., Conklin, D.J., O’Toole, T.E., } \\
\text { McCracken, J., Lorkiewicz, P., Xie, Z., Zafar, N., Krishnasamy, S.S., Srivastava, S., Finch, J., Keith, R.J., DeFilippis, } \\
\text { A., Rai, S.N., Liu, G., Bhatnagar, A. (2018). Association between residential greenness and cardiovascular disease risk. } \\
\text { Journal of the American Heart Association. http://doi: 10.1161/JAHA.118.009117. }\end{array}$} \\
\hline Purpose & Population & Demographic & Methods & NDVI Range & $\begin{array}{l}\text { Physiologic } \\
\text { Outcome }\end{array}$ \\
\hline $\begin{array}{l}\text { To study if } \\
\text { residential } \\
\text { exposure to green } \\
\text { space would } \\
\text { reduce the risk of } \\
\text { cardiovascular } \\
\text { disease (CVD) by } \\
\text { decreasing } \\
\text { sympathetic } \\
\text { nervous system } \\
\text { (SNS) activation. }\end{array}$ & $\begin{array}{l}408 \text { participants } \\
\text { from the } \\
\text { University of } \\
\text { Louisville } \\
\text { outpatient } \\
\text { cardiology clinic } \\
\text { participated in the } \\
\text { study. }\end{array}$ & $\begin{array}{l}\text { Participants were } \\
\text { adults age } 51.4+/- \\
10.8 \text { years old. } \\
52 \% \text { were males. } \\
56 \% \text { were white, } \\
39 \% \text { were black } \\
\text { and } 5 \% \text { were other } \\
\text { races. The } \\
\text { participants were } \\
\text { patients at the } \\
\text { outpatient } \\
\text { cardiology clinic } \\
\text { and had history of } \\
\text { hypertension, } \\
\text { hyperlipidemia } \\
\text { and were } \\
\text { considered at risk } \\
\text { for major CVD } \\
\text { incident based on } \\
\text { the Framingham } \\
\text { Risk Score. }\end{array}$ & $\begin{array}{l}\text { Participants had } \\
\text { blood and urine } \\
\text { samples drawn } \\
\text { between 1:00pm } \\
\text { and 4:00pm EST } \\
\text { to reduce } \\
\text { variability in } \\
\text { circadian rhythm. } \\
\text { Catecholamines, } \\
\text { monoamines and } \\
\text { their metabolites in } \\
\text { urine samples were } \\
\text { measured. } \\
\text { Oxidative stress } \\
\text { was measured by } \\
\text { observing levels of } \\
\text { F2-isoprotane and } \\
\text { its metabolites in } \\
\text { the urine samples. } \\
\text { Endothelial repair } \\
\text { capacity was } \\
\text { measured by } \\
\text { observing different }\end{array}$ & $\begin{array}{l}\text { NDVI was } \\
\text { classified as high } \\
(>0.55) \text {, medium } \\
(0.36-0.54) \text { and } \\
\text { low }(<0.36) \text { at } \\
250-m \text { around the } \\
\text { participants' } \\
\text { homes. The } 250-m \\
\text { radius was the } \\
\text { measurement used } \\
\text { in the final } \\
\text { analysis of this } \\
\text { study. }\end{array}$ & $\begin{array}{l}\text { In fully adjusted } \\
\text { models, higher } \\
\text { levels of NDVI } \\
\text { were associated } \\
\text { with lower levels } \\
\text { of urinary } \\
\text { epinephrine. Each } \\
0.1 \text { unit increase in } \\
\text { NDVI was } \\
\text { associated with } \\
6.9 \% \text { lower levels } \\
\text { of urinary } \\
\text { epinephrine, } \\
\text { however there was } \\
\text { no statistical } \\
\text { significance for the } \\
\text { other } \\
\text { catecholamines, } \\
\text { monoamine and } \\
\text { metabolites } \\
\text { measured. Urinary } \\
\text { levels of F2- } \\
\text { isoprotane were }\end{array}$ \\
\hline
\end{tabular}




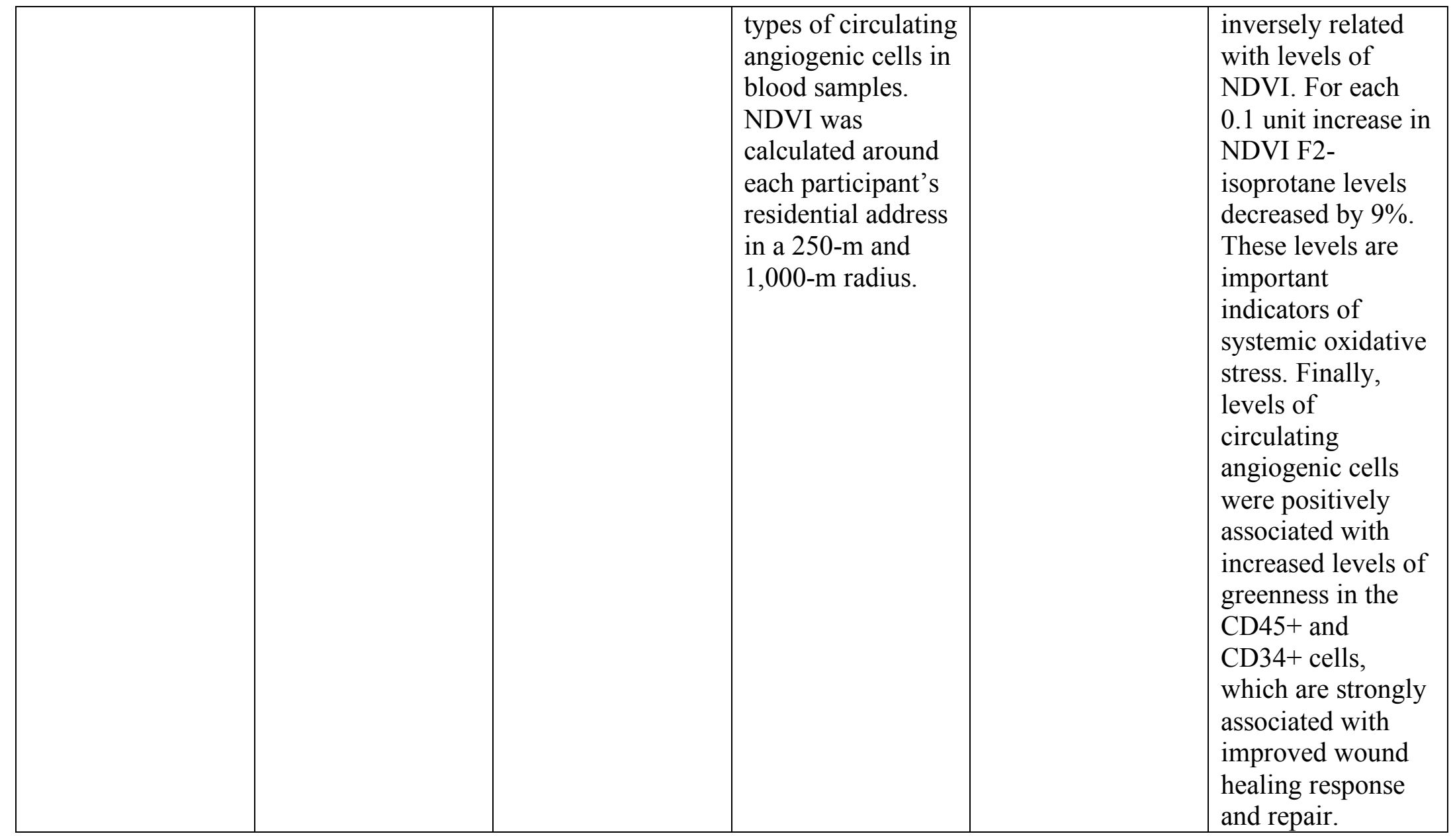


Table C3-

\begin{tabular}{|c|c|c|c|c|c|}
\hline \multicolumn{6}{|c|}{$\begin{array}{l}\text { Pereira, G., Foster, S., Martin, K., Christian, H., Boruff, B. J., Knuiman, M., \& Giles-Corti, B. } \\
\text { (2012). The association between neighborhood greenness and cardiovascular disease: an observational study. BMC } \\
\text { Public Health 12(466). http://doi.org/10.1186/1417-2458-12-466 }\end{array}$} \\
\hline Purpose & Population & Demographic & Methods & NDVI Range & $\begin{array}{l}\text { Physiologic } \\
\text { Outcome }\end{array}$ \\
\hline $\begin{array}{l}\text { Identify if mean } \\
\text { neighborhood } \\
\text { greenness is } \\
\text { associated with } \\
\text { decreased hospital } \\
\text { admission and } \\
\text { self-reported } \\
\text { medically } \\
\text { diagnosed } \\
\text { coronary heart } \\
\text { disease or stroke. }\end{array}$ & $\begin{array}{l}11,404 \text { adults from } \\
\text { the Western } \\
\text { Australia Health } \\
\text { and Wellbeing } \\
\text { Survey that took } \\
\text { place between } \\
2003-2009 \text { agreed } \\
\text { to participate in } \\
\text { the study. }\end{array}$ & $\begin{array}{l}\text { The cohort } \\
\text { included adults age } \\
25 \text { and greater who } \\
\text { were residents of } \\
\text { the Perth } \\
\text { metropolitan area } \\
\text { in Australia. }\end{array}$ & $\begin{array}{l}\text { Survey results } \\
\text { from the } \\
\text { participants were } \\
\text { obtained. } \\
\text { Participants were } \\
\text { identified as } \\
\text { having coronary } \\
\text { heart disease or } \\
\text { stroke from } \\
\text { medical records } \\
\text { that coded for the } \\
\text { two. } 367 \\
\text { participants' (3\%) } \\
\text { were identified as } \\
\text { being hospitalized } \\
\text { with coronary } \\
\text { heart disease or } \\
\text { stroke and } 1,415 \\
\text { (12\%) were } \\
\text { diagnosed with } \\
\text { coronary heart } \\
\text { disease or stroke. } \\
\text { NDVI was } \\
\text { calculated in a } \\
1600 \mathrm{~m} \text { radius } \\
\text { around each }\end{array}$ & $\begin{array}{l}\text { Greenness ranged } \\
\text { from a low NDVI } \\
\text { of }-0.059 \text { to a high } \\
\text { of } 0.337 \text {. Variation } \\
\text { of greenness was } \\
\text { also measured and } \\
\text { areas with low } \\
\text { variation had a } \\
\text { green standard } \\
\text { deviation of } 0.048 \text {. } \\
\text { Areas with high } \\
\text { variation had a } \\
\text { green standard } \\
\text { deviation of } 0.205 .\end{array}$ & $\begin{array}{l}\text { Results showed } \\
\text { limited statistical } \\
\text { significance for } \\
\text { participants living } \\
\text { in areas of } \\
\text { increased mean } \\
\text { greenness as } \\
\text { opposed to areas of } \\
\text { low greenness. } \\
\text { Statistical } \\
\text { significance was } \\
\text { found in } \\
\text { participants who } \\
\text { lived in areas of } \\
\text { high green } \\
\text { variability with a } \\
37 \% \text { lower rate of } \\
\text { hospital admission } \\
\text { for heart disease or } \\
\text { stroke as opposed } \\
\text { to those who lived } \\
\text { in areas of low } \\
\text { variability in green } \\
\text { spaces. }\end{array}$ \\
\hline
\end{tabular}




\begin{tabular}{|l|l|l|l|l|l|}
\hline & & & participant's home. & & \\
\hline
\end{tabular}


Table C4-

\begin{tabular}{|c|c|c|c|c|c|}
\hline \multicolumn{6}{|c|}{$\begin{array}{l}\text { Pereira, G., Christian, H., Foster, S., Boruff, B. J., Knuiman, M., Giles-Corti, B. (2013, June 9). } \\
\text { The association between neighborhood greenness and weight status: An observational study in Perth Western Australia. } \\
\text { Environmental Health, 12(29). http://doi:10.1186/1476-069X-12-49. }\end{array}$} \\
\hline Purpose & Population & Demographic & Methods & NDVI Range & $\begin{array}{l}\text { Physiologic } \\
\text { Outcome }\end{array}$ \\
\hline $\begin{array}{l}\text { Investigate the } \\
\text { association } \\
\text { between } \\
\text { neighborhood } \\
\text { green space and } \\
\text { the incidences of } \\
\text { overweight or } \\
\text { obese participants. }\end{array}$ & $\begin{array}{l}10,208 \text { adult } \\
\text { participants from } \\
\text { the Western } \\
\text { Australian Health } \\
\text { and Wellbeing } \\
\text { Survey between } \\
2004 \text { and } 2009 \\
\text { agreed to } \\
\text { participate in the } \\
\text { study. }\end{array}$ & $\begin{array}{l}\text { Participants were } \\
\text { age } 16 \text { to greater } \\
\text { than } 65 \text { years old } \\
\text { who were residents } \\
\text { of the Perth } \\
\text { metropolitan area } \\
\text { in Australia. }\end{array}$ & $\begin{array}{l}\text { Self-reported } \\
\text { height and weight } \\
\text { were obtained } \\
\text { from the survey in } \\
\text { order to calculate } \\
\text { participants' body } \\
\text { mass index (BMI). } \\
\text { BMI was } \\
\text { considered obese } \\
\text { or } \\
\text { overweight/obese } \\
\text { if it was greater tan } \\
30 \text { or greater than } \\
25 \text { respectively. } \\
\text { Greenness was } \\
\text { measured by } \\
\text { calculating NDVI } \\
\text { in a } 1,600-m \text { area } \\
\text { surrounding the } \\
\text { participants' } \\
\text { residential address. }\end{array}$ & $\begin{array}{l}\text { Greenness ranged } \\
\text { from a low NDVI } \\
\text { of }-0.059 \text { to a high } \\
\text { of } 0.337 \text {. Variation } \\
\text { of greenness was } \\
\text { also measured and } \\
\text { ranged from } 0.048 \\
\text { to } 0.205 \text {. }\end{array}$ & $\begin{array}{l}\text { After full } \\
\text { adjustment for age, } \\
\text { sex, education, } \\
\text { dietary and } \\
\text { smoking habits, } \\
\text { statistically } \\
\text { significant results } \\
\text { showed that the } \\
\text { odds ratio for } \\
\text { being } \\
\text { overweight/obese } \\
\text { and the odds ratio } \\
\text { for being obese } \\
\text { were higher in } \\
\text { adults who lived in } \\
\text { lower areas of } \\
\text { greenness. Reports } \\
\text { of } \\
\text { overweight/obese } \\
\text { individuals were } \\
16 \% \text { lower in areas } \\
\text { of high greenness } \\
\text { as opposed to areas } \\
\text { of low greenness. } \\
\text { Similarly, reports }\end{array}$ \\
\hline
\end{tabular}




\begin{tabular}{|l|l|l|l|l|}
\hline & & & & $\begin{array}{l}\text { of obesity were } \\
22 \% \text { lower in areas } \\
\text { of high greenness } \\
\text { as opposed to areas } \\
\text { of low greenness. } \\
\text { Results were even } \\
\text { stronger for areas } \\
\text { of high variability } \\
\text { of greenness with a } \\
\text { matching } 25 \% \text { less } \\
\text { reporting for } \\
\text { overweight/obese } \\
\text { and obese } \\
\text { participants in high } \\
\text { variability as } \\
\text { opposed to low. }\end{array}$ \\
& & & & \\
& & & & \\
& & & &
\end{tabular}


Table C5-

\begin{tabular}{|c|c|c|c|c|c|}
\hline \multicolumn{6}{|c|}{$\begin{array}{l}\text { Huang, W., Yang, B., Yu, H., Bloom, M.S., Markevych, I., Heinrich, J., Knibbs, L,D., } \\
\text { Leskinen, A., Dharmage, S.C., Jalaludin, B., Morawska, L., Jalava, P., Guo, Y., Lin, S., Zhou, Y., Liu, R., Feng, D., } \\
\text { Hu, L., Zeng, X...Dong, G. (2019). Association between community greenness and obesity in urban-dwelling Chinese } \\
\text { adults. Science of the Total Environment } 702 \text { (2020). http://doi.org/10.1016/j.scitotenv.2019.125040. }\end{array}$} \\
\hline Purpose & \begin{tabular}{|l|} 
Population \\
\end{tabular} & Demographic & Methods & NDVI Range & $\begin{array}{c}\text { Physiologic } \\
\text { Outcome }\end{array}$ \\
\hline $\begin{array}{l}\text { Investigate the } \\
\text { relationship } \\
\text { between living in } \\
\text { areas with higher } \\
\text { levels of green } \\
\text { spaces and the } \\
\text { prevalence of } \\
\text { obesity and } \\
\text { indicators of } \\
\text { adiposity. }\end{array}$ & $\begin{array}{l}24,845 \text { participants } \\
\text { enrolled in the } \\
\text { study. The } \\
\text { participants had } \\
\text { already completed } \\
\text { the } 33 \\
\text { Communities } \\
\text { Chinese Health } \\
\text { Study in } 2009 \text {. }\end{array}$ & $\begin{array}{l}\text { All study } \\
\text { participants were } \\
\text { greater than } 18 \\
\text { years old. Mean } \\
\text { BMI for the } \\
\text { participant group } \\
\text { was } 24.40 \mathrm{~kg} / \mathrm{m} 2 \text {. } \\
\text { Mean waist } \\
\text { circumference for } \\
\text { the participants } \\
\text { was } 83.24 \mathrm{~cm} \text {. }\end{array}$ & $\begin{array}{l}\text { Participants } \\
\text { completed a } \\
\text { standardized } \\
\text { questionnaire to } \\
\text { provide their } \\
\text { demographic } \\
\text { information. } \\
\text { Community NDVI } \\
\text { was calculated } \\
\text { using satellite } \\
\text { imagery. Central } \\
\text { and peripheral } \\
\text { obesity were } \\
\text { calculated from } \\
\text { obtaining height, } \\
\text { weight, and waist } \\
\text { circumference } \\
\text { measurements for } \\
\text { the study } \\
\text { participants. }\end{array}$ & $\begin{array}{l}\text { NDVI ranged from } \\
\text { low of } 0.18 \text { to a } \\
\text { high of } 0.80 . \\
\text { NDVI was } \\
\text { calculated at a } \\
500 \text {-m radius from } \\
\text { the participants' } \\
\text { community. }\end{array}$ & $\begin{array}{l}\text { Each } 0.17 \text { unit } \\
\text { increase in NDVI } \\
\text { was associated } \\
\text { with } 20 \% \text { lower } \\
\text { odds for peripheral } \\
\text { obesity and } 12 \% \\
\text { lower odds for } \\
\text { central obesity. } \\
\text { Stronger benefits } \\
\text { were noted in } \\
\text { those participants } \\
\text { who were }>55 \\
\text { years old. }\end{array}$ \\
\hline
\end{tabular}


Table C6-

\begin{tabular}{|c|c|c|c|c|c|}
\hline \multicolumn{6}{|c|}{$\begin{array}{l}\text { Yang, B., Markevych, I., Heinrich, J., Bowatte, G., Bloom, M.S., Guo, Y., Dharmage, S.C., } \\
\text { Jalaludin, B., Knibbs, L.D., Morawska, L., Qian, Z., Chen, D., Ma, H., Chen, D., Lin, S., Yan, M., Liu, K., Zeng, X., } \\
\text { Hu, 1., Dong, G. (2018, December 2). Associations of greenness with diabetes mellitus and glucose-homeostasis } \\
\text { markers: The } 33 \text { Communities Chinese Health Study. International Journal of Hygiene and Environmental Health, } 222 \\
\text { (2019), 283-290. http://doi.org/10.1016/j.ijheh.2018.12.001. }\end{array}$} \\
\hline Purpose & Population & Demographic & Methods & NDVI Range & $\begin{array}{l}\text { Physiologic } \\
\text { Outcome }\end{array}$ \\
\hline $\begin{array}{l}\text { Investigate if } \\
\text { living in areas with } \\
\text { higher levels of } \\
\text { green space lead to } \\
\text { lower prevalence } \\
\text { of diabetes } \\
\text { mellitus. Study the } \\
\text { association } \\
\text { between green } \\
\text { spaces and } \\
\text { changes in glucose } \\
\text { homeostasis } \\
\text { markers that can } \\
\text { lead to the } \\
\text { development of } \\
\text { diabetes mellitus. }\end{array}$ & $\begin{array}{l}15,477 \text { participants } \\
\text { were included in } \\
\text { the final analysis } \\
\text { of the study. } \\
\text { Participants had } \\
\text { participated in the } \\
33 \text { Communities } \\
\text { Chinese Health } \\
\text { Study that was } \\
\text { conducted in } 2009 \text {. }\end{array}$ & $\begin{array}{l}\text { Participants were } \\
\text { age } 18-74 \text { years } \\
\text { old and lived in } \\
\text { various cities } \\
\text { across Northeast } \\
\text { China in the } \\
\text { Liaoning province. }\end{array}$ & $\begin{array}{l}\text { Each participant's } \\
\text { fasting and two- } \\
\text { hour blood glucose } \\
\text { and insulin levels } \\
\text { were drawn } \\
\text { following an oral } \\
\text { glucose tolerance } \\
\text { test (GTT). Insulin } \\
\text { resistance and beta } \\
\text { cell function were } \\
\text { determined using } \\
\text { the homeostasis } \\
\text { model of insulin } \\
\text { resistance and beta } \\
\text { cell function } \\
\text { respectively. } \\
\text { Diabetes was } \\
\text { defined per the } \\
\text { American Diabetes } \\
\text { Association as } \\
\text { fasting glucose } \\
>7 \text { mmol/L or two } \\
\text { our glucose }\end{array}$ & $\begin{array}{l}\text { NDVI ranged from } \\
0.18 \text { to } 0.80 \text { in a } \\
500-\mathrm{m} \text { radius } \\
\text { around the } \\
\text { participants' } \\
\text { communities. }\end{array}$ & $\begin{array}{l}\text { The mean age of } \\
\text { the participants } \\
\text { was } 45 \text { years old. } \\
\text { A } 0.1 \text {-unit increase } \\
\text { in NDVI at a 500- } \\
\text { m radius around } \\
\text { participants' } \\
\text { community } \\
\text { correlated with } \\
12 \% \text { lower odds } \\
\text { for prevalence of } \\
\text { diabetes mellitus. } \\
\text { Furthermore, } \\
\text { fasting glucose } \\
\text { was } 1.14 \% \text { lower } \\
\text { with each } 0.1 \text { unit } \\
\text { increase in NDVI } \\
\text { as well as } 2.03 \% \\
\text { lower } 2 \text {-hour } \\
\text { glucose and } 1.66 \% \\
\text { lower } 2 \text {-hour } \\
\text { insulin. Insulin } \\
\text { resistance was }\end{array}$ \\
\hline
\end{tabular}




\begin{tabular}{|l|l|l|l|}
\hline & & $\begin{array}{l}>11.0 \mathrm{mmol} / \mathrm{L}, \text { or } \\
\text { the use of an anti- } \\
\text { diabetic } \\
\text { medication. } \\
\text { Community } \\
\text { greenness was } \\
\text { calculated for each } \\
\text { participant using } \\
\text { NDVI in a 100-m, } \\
\text { each unit increase } \\
\text { and beta cell } \\
\text { function was } \\
3.33 \% \text { higher with } \\
\text { each increase in } \\
\text { NDVI. } \\
\text { radius. Ond the } \\
500 \text {-m calculation } \\
\text { was used in the } \\
\text { final analysis. }\end{array}$ \\
& \\
&
\end{tabular}


Appendix D

Critical Appraisal Skills Programme (CASP) Tables

\begin{tabular}{|c|c|c|c|}
\hline 12 Questions & Yes & $\begin{array}{c}\text { Can't } \\
\text { Tell }\end{array}$ & No \\
\hline 1. Was there a clear question for the study to address? & & & \\
\hline $\begin{array}{l}\text { 2. Was there a comparison with an appropriate reference } \\
\text { standard? }\end{array}$ & & & \\
\hline 3. Did all patients get the diagnostic test and reference standard? & & & \\
\hline $\begin{array}{l}\text { 4. Could the results of the test have been influenced by the results } \\
\text { of the reference standard? }\end{array}$ & & & \\
\hline 5. Is the disease status of the tested population clearly described? & & & \\
\hline $\begin{array}{l}\text { 6. Were the methods for performing the test described in } \\
\text { sufficient detail? }\end{array}$ & & & \\
\hline 7. What are the results? & & & \\
\hline $\begin{array}{l}\text { 8. How sure are we about the results? Consequences and cost of } \\
\text { alternatives performed? }\end{array}$ & & & \\
\hline $\begin{array}{l}\text { 9. Can the results be applied to your patients/the population of } \\
\text { interest? }\end{array}$ & & & \\
\hline $\begin{array}{l}\text { 10. Can the test be applied to your patient or population of } \\
\text { interest? }\end{array}$ & & & \\
\hline $\begin{array}{l}\text { 11. Were all outcomes important to the individual or population } \\
\text { considered? }\end{array}$ & & & \\
\hline $\begin{array}{l}\text { 12. What would be the impact of using this test on your } \\
\text { patients/population? }\end{array}$ & & & \\
\hline
\end{tabular}


Table D1-

Study 1: James, P., Hart, J. E., Banay, R. F., Laden, F. (2016). Exposure to greenness and mortality in a nationwide prospective cohort study of women. Environmental Health Perspectives, 124 (9), 1344-1352. http://doi. 10.1289/ehp.1510363.

\begin{tabular}{|c|c|c|c|}
\hline 12 Questions & Yes & $\begin{array}{c}\text { Can't } \\
\text { Tell }\end{array}$ & No \\
\hline $\begin{array}{l}\text { Was there a clear question for the study to address? The study } \\
\text { hypothesizes if higher levels of surrounding greenness would lead } \\
\text { to lower rates of all-cause, cancer, respiratory, and cardiovascular } \\
\text { mortality. }\end{array}$ & $\sqrt{ }$ & & \\
\hline $\begin{array}{l}\text { Was there a comparison with an appropriate reference } \\
\text { standard? The studied compared results of reported causes of } \\
\text { mortality to the deceased person's available greenness outside of } \\
\text { their home. The level of greenness within a } 250 \text {-m radius directly } \\
\text { outside the home and greenness within a } 1,250-\mathrm{m} \text { radius, which is a } \\
\text { ten-to-fifteen-minute walk outside the home, was measured using } \\
\text { the NDVI scale. }\end{array}$ & $\sqrt{ }$ & & \\
\hline $\begin{array}{l}\text { Did all patients get the diagnostic test and reference standard? } \\
\text { All of the observed patients in the study ( } \mathrm{n}=108,630) \text { were accessed } \\
\text { through reviewing the results from the Nurses' Health Study. This } \\
\text { is a cohort study that assesses risk factors for chronic disease in } \\
\text { women. The study began in } 1976 \text { and the women were asked to fill } \\
\text { out a biennial questionnaire that contains information about various } \\
\text { health-related exposures and diagnoses. In } 2000 \text {, the addresses of } \\
\text { those still alive were geocoded to decipher the NDVI in their } \\
\text { residential area. The deaths that occurred between the year } 2000 \text { and } \\
2008 \text { were then assessed, and death certificates were reviewed by a } \\
\text { physician to classify the primary cause of death }\end{array}$ & $\sqrt{ }$ & & \\
\hline $\begin{array}{l}\text { Could the results of the test have been influenced by the results } \\
\text { of the reference standard? Since this study utilized data that had } \\
\text { been previously recorded as part of the Nurses' Health Study (NHS) } \\
\text { and then compared to the level of greenness surrounding the } \\
\text { residential area of each participant in the NHS, the results could not } \\
\text { have been influenced by the reference standard because the two } \\
\text { were separate entities. }\end{array}$ & & & $\sqrt{ }$ \\
\hline $\begin{array}{l}\text { Is the disease status of the tested population clearly described? } \\
\text { The study states it observed causes of death between the years } 2000 \\
\text { and } 2008 \text { for the study participants. } 8,604 \text { deaths were observed } \\
\text { from the } 108,630 \text { participants eligible for the study. Causes of death } \\
\text { were then classified as either respiratory in nature, related to cancer, } \\
\text { kidney disease, stroke, coronary heart disease, diabetes or infection. }\end{array}$ & $\sqrt{ }$ & & \\
\hline $\begin{array}{l}\text { Were the methods for performing the test described in } \\
\text { sufficient detail? The data was obtained from the Nurses' Health } \\
\text { Study cohort. Using satellite imagery, the total greenness was } \\
\text { calculated as NDVI surrounding the participant's residence at the }\end{array}$ & $\sqrt{ }$ & & \\
\hline
\end{tabular}




\begin{tabular}{|c|c|c|c|}
\hline time of their death. & & & \\
\hline $\begin{array}{l}\text { What are the results? The results of the study found a } 12 \% \text { lower } \\
\text { all-cause mortality rate in those living in the highest quintile of } \\
\text { cumulative average greenness around the } 250-\mathrm{m} \text { area surrounding } \\
\text { their residence as opposed to those who lived in areas with the } \\
\text { lowest levels of green space. There were similar results for those in } \\
\text { the } 1,250-\mathrm{m} \text { radius, but they were less consistent. These results } \\
\text { were concluded after age adjusted ratios were completed. Areas of } \\
\text { highest greenness had NDVI as } 0.62 \text { as compared to areas of lowest } \\
\text { greenness, which were reported as NDVI of } 0.47 \text {. When looking at } \\
\text { specific cause of death there was no statistical significance between } \\
\text { greenness and mortality from cardiovascular disease, diabetes or } \\
\text { infections. }\end{array}$ & $\mathrm{N} / \mathrm{A}$ & $\mathrm{N} / \mathrm{A}$ & $\mathrm{N} / \mathrm{A}$ \\
\hline $\begin{array}{l}\text { How sure are we about the results? Consequences and cost of } \\
\text { alternatives performed? Confidence interval of } 95 \% \text { was reported } \\
\text { for the result findings. }\end{array}$ & N/A & $\mathrm{N} / \mathrm{A}$ & $\mathrm{N} / \mathrm{A}$ \\
\hline $\begin{array}{l}\text { Can the results be applied to your patients/the population of } \\
\text { interest? The participants in this study were from various areas } \\
\text { across the United States. }\end{array}$ & $\sqrt{ }$ & & \\
\hline $\begin{array}{l}\text { Can the test be applied to your patient or population of } \\
\text { interest? The participants in this study were from various areas } \\
\text { across the United States. }\end{array}$ & $\sqrt{ }$ & & \\
\hline $\begin{array}{l}\text { Were all outcomes important to the individual or population } \\
\text { considered? The conclusion of the study states that the findings } \\
\text { suggest that vegetation has a protective effect on health and } \\
\text { therefore policies should exist to increase green spaces in urban and } \\
\text { rural areas. }\end{array}$ & $\sqrt{ }$ & & \\
\hline $\begin{array}{l}\text { What would be the impact of using this test on your } \\
\text { patients/population? Verify the results of the test in various } \\
\text { geographic regions. Confirm need for green space as health } \\
\text { determinant. }\end{array}$ & N/A & $\mathrm{N} / \mathrm{A}$ & $\mathrm{N} / \mathrm{A}$ \\
\hline
\end{tabular}


Table D2-

Study 2: Yeager, R., Riggs, D., DeJarnett, N., Tollerud, D.J., Wilson, J., Conklin, D.J., O’Toole, T.E., McCracken, J., Lorkiewicz, P., Xie, Z., Zafar, N., Krishnasamy, S.S., Srivastava, S., Finch, J., Keith, R.J., DeFilippis, A., Rai, S.N., Liu, G., Bhatnagar, A. (2018). Association between residential greenness and cardiovascular disease risk. Journal of the American Heart Association. http://doi: 10.1161/JAHA.118.009117.

\begin{tabular}{|c|c|c|c|}
\hline 12 Questions & Yes & $\begin{array}{c}\text { Can't } \\
\text { Tell }\end{array}$ & No \\
\hline $\begin{array}{l}\text { Was there a clear question for the study to address? The study } \\
\text { tested the hypothesis that residential exposure to green spaces could } \\
\text { reduce the risk of cardiovascular disease (CVD) by decreasing } \\
\text { sympathetic nervous system (SNS) activation. The study was } \\
\text { conducted by evaluating potential pathophysiologic links between } \\
\text { neighborhood greenness and urinary levels of catecholamines. } \\
\text { Increased levels of catecholamines are associated with activation of } \\
\text { SNS, which can lead to physiologic changes that can lead to CVD. }\end{array}$ & $\sqrt{ }$ & & \\
\hline $\begin{array}{l}\text { Was there a comparison with an appropriate reference } \\
\text { standard? The participants were all patients at the outpatient } \\
\text { cardiology clinic of the University of Louisville. They were } \\
\text { identified as being at risk for developing CVD. NDVI was used as a } \\
\text { measurement of greenness. }\end{array}$ & $\sqrt{ }$ & & \\
\hline $\begin{array}{l}\text { Did all patients get the diagnostic test and reference standard? } \\
\text { All participants had their blood and urine samples taken between } \\
\text { 1:00 and 4:00pm EST to reduce circadian variability. } \\
\text { Catecholamines in urine samples were measured using ultra } \\
\text { performance liquid chromatography-tandem mass spectrometry } \\
\text { analysis. Blood samples measured circulating angiogenic cells. } \\
\text { NDVI was calculated for a } 250-\mathrm{m} \text { and } 1000-\mathrm{m} \text { radius around each } \\
\text { participant's home. }\end{array}$ & $\sqrt{ }$ & & \\
\hline $\begin{array}{l}\text { Could the results of the test have been influenced by the results } \\
\text { of the reference standard? Being a retrospective study, blinding } \\
\text { was not applied, as it was not an appropriate measure for this study. }\end{array}$ & & & $\sqrt{ }$ \\
\hline $\begin{array}{l}\text { Is the disease status of the tested population clearly described? } \\
\text { All of the participants were identified as patients of the outpatient } \\
\text { cardiology clinic of the University of Louisville. The clinic follows } \\
\text { patients with preexisting CVD or at risk for CVD. }\end{array}$ & $\sqrt{ }$ & & \\
\hline $\begin{array}{l}\text { Were the methods for performing the test described in } \\
\text { sufficient detail? The study population was discussed in detail. } \\
\text { Furthermore, the residential location of the participants was } \\
\text { identified based on their record and NDVI was calculated for that } \\
\text { particular area. Urine and blood specimens were collected at the } \\
\text { same time of day for each participant. Urine samples were then } \\
\text { assessed for a variety of catecholamines, monoamines and their } \\
\text { metabolites. Blood specimens were assessed for circulating } \\
\text { angiogenic cells as a measure of endothelial repair capacity. The }\end{array}$ & $\sqrt{ }$ & & \\
\hline
\end{tabular}




\begin{tabular}{|c|c|c|c|}
\hline process of extracting these levels is reviewed in detail. & & & \\
\hline $\begin{array}{l}\text { What are the results? } 408 \text { participants were included in the final } \\
\text { analysis of the study. } 52 \% \text { male and } 56 \% \text { white, } 39 \% \text { black and } 5 \% \\
\text { other races. The cohort was at risk for CVD and had a history of } \\
\text { hyperlipidemia, and/or hypertension. Average age of participant } \\
\text { was } 51.4+/-10.8 \text { years. In fully adjusted models for age, sex, race, } \\
\text { smoking status, neighborhood deprivation and statin use it was } \\
\text { found that urinary levels of epinephrine were inversely related with } \\
\text { NDVI levels in a } 250 \text {-m radius around the participant's homes. This } \\
\text { level continued to be significant in the } 1000 \text {-m radius around the } \\
\text { home. This relationship did not exist for levels of norepinephrine. } \\
\text { Inverse levels between NDVI and F2-isoprotane were also } \\
\text { identified. Finally, there was a positive relationship between } \\
\text { circulating angiogenic cells and increased levels of NDVI. }\end{array}$ & $\mathrm{N} / \mathrm{A}$ & $\mathrm{N} / \mathrm{A}$ & $\mathrm{N} / \mathrm{A}$ \\
\hline $\begin{array}{l}\text { How sure are we about the results? Consequences and cost of } \\
\text { alternatives performed? The consistency of the results showed } \\
\text { inverse relationships between NDVI levels and various biomarkers } \\
\text { of stress that can lead to CVD supports the author's claims that } \\
\text { greenness is associated with cardiovascular wellness. Results were } \\
\text { reported with } 95 \% \text { confidence intervals. }\end{array}$ & $\mathrm{N} / \mathrm{A}$ & $\mathrm{N} / \mathrm{A}$ & $\mathrm{N} / \mathrm{A}$ \\
\hline $\begin{array}{l}\text { Can the results be applied to your patients/the population of } \\
\text { interest? The results of the study provide information about an } \\
\text { adult cohort at risk for CVD. This cohort has strong relations to the } \\
\text { population of patients seen by the acute care advanced practice } \\
\text { nurse. }\end{array}$ & $\sqrt{ }$ & & \\
\hline $\begin{array}{l}\text { Can the test be applied to your patient or population of } \\
\text { interest? This test could be applied to any population of patients. }\end{array}$ & $\sqrt{ }$ & & \\
\hline $\begin{array}{l}\text { Were all outcomes important to the individual or population } \\
\text { considered? This analysis of the results of this study support the } \\
\text { claim that those who live in greener surroundings have lower levels } \\
\text { of SNS activation, oxidative stress and higher levels of endothelial } \\
\text { damage repair capacity. }\end{array}$ & $\sqrt{ }$ & & \\
\hline $\begin{array}{l}\text { What would be the impact of using this test on your } \\
\text { patients/population? Patients would be able to understand more } \\
\text { fully what their risk factors are for developing CVD. }\end{array}$ & $\mathrm{N} / \mathrm{A}$ & $\mathrm{N} / \mathrm{A}$ & $\mathrm{N} / \mathrm{A}$ \\
\hline
\end{tabular}


Table D3-

\begin{tabular}{|c|c|c|c|}
\hline $\begin{array}{l}\text { Study 3: Pereira, G., Foster, S., Martin, K., Christian, H., Boruff, B. } \\
\text { Giles-Corti, B. (2012). The association between neighborhood green } \\
\text { cardiovascular disease: an observational study. BMC Public Health } \\
\text { http://doi.org/10.1186/1417-2458-12-466 }\end{array}$ & $\begin{array}{l}\text { Kn } \\
\text { ess a } \\
\text { (46) }\end{array}$ & & \\
\hline 12 Questions & Yes & $\begin{array}{c}\text { Can't } \\
\text { Tell } \\
\end{array}$ & No \\
\hline $\begin{array}{l}\text { Was there a clear question for the study to address? Mean } \\
\text { neighborhood greenness is associated with decreased hospital } \\
\text { admission and self-reported medically diagnosed coronary heart } \\
\text { disease or stroke. }\end{array}$ & $\sqrt{ }$ & & \\
\hline $\begin{array}{l}\text { Was there a comparison with an appropriate reference } \\
\text { standard? 11,404 adults agreed to participate in the Western } \\
\text { Australian Health and Wellbeing Survey between } 2003-2009 \text { and } \\
\text { have their data utilized in this study. Participants were identified as } \\
\text { having coronary heart disease or stroke from medical records that } \\
\text { coded for coronary heart disease or stroke as the primary diagnosis. } \\
\text { NDVI was used as the reference standard for evaluating levels of } \\
\text { greenness within a 1600-m distance surrounding the participants' } \\
\text { homes. }\end{array}$ & $\sqrt{ }$ & & \\
\hline $\begin{array}{l}\text { Did all patients get the diagnostic test and reference standard? } \\
\text { Every participant took the Western Australian Health and } \\
\text { Wellbeing Survey and then was assessed for a diagnosis of coronary } \\
\text { heart disease or stroke. Greenness was measured using NDVI in } \\
\text { their neighborhoods. }\end{array}$ & $\sqrt{ }$ & & \\
\hline $\begin{array}{l}\text { Could the results of the test have been influenced by the results } \\
\text { of the reference standard? No. The reference standard is } \\
\text { confirmed medical records coded for primary diagnosis of heart } \\
\text { disease or stroke and NDVI as a scale for greenness. }\end{array}$ & & & $\sqrt{ }$ \\
\hline $\begin{array}{l}\text { Is the disease status of the tested population clearly described? } \\
\text { Disease status is identified as having ever been diagnosed with } \\
\text { coronary heart disease or stroke, or having been hospitalized with } \\
\text { coronary heart disease or stroke. }\end{array}$ & $\sqrt{ }$ & & \\
\hline $\begin{array}{l}\text { Were the methods for performing the test described in } \\
\text { sufficient detail? Yes, of the } 11,404 \text { survey participants, } 367 \text { were } \\
\text { hospitalized and } 1,415 \text { were diagnosed with coronary heart disease } \\
\text { or stroke. NDVI was calculated in a } 1600 \text {-m area surrounding the } \\
\text { participant's home. Water spaces were removed from the analysis } \\
\text { before NDVI was calculated. } 1600 \text {-m were chosen as an acceptable } \\
\text { range because it was considered within } 15 \text { minutes walking distance } \\
\text { of the participants' homes. A full adjustment was made for socio- } \\
\text { demographic factors of age, sex, healthcare card, education, and } \\
\text { household income, diabetes, BMI, hypertension, high cholesterol, } \\
\text { dietary patterns, smoking history and air quality. }\end{array}$ & $\sqrt{ }$ & & \\
\hline What are the results? The odds of self-reported coronary heart & $\mathrm{N} / \mathrm{A}$ & $\mathrm{N} / \mathrm{A}$ & $\mathrm{N} / \mathrm{A}$ \\
\hline
\end{tabular}




\begin{tabular}{|c|c|c|c|}
\hline $\begin{array}{l}\text { disease or stroke was } 0.76 \text { in areas of moderate variability and } 0.84 \\
\text { in areas with high variability of greenness. The odds of hospital } \\
\text { admission for coronary heart disease were } 0.85 \text { for areas of } \\
\text { moderate green variability and } 0.63 \text { in areas of high green } \\
\text { variability. }\end{array}$ & & & \\
\hline $\begin{array}{l}\text { How sure are we about the results? Consequences and cost of } \\
\text { alternatives performed? Results were reported with confidence } \\
\text { intervals of } 95 \% \text {. There were no additional costs to the study since } \\
\text { data had previously been collected for the Western Australian } \\
\text { Health Study. }\end{array}$ & $\mathrm{N} / \mathrm{A}$ & $\mathrm{N} / \mathrm{A}$ & $\mathrm{N} / \mathrm{A}$ \\
\hline $\begin{array}{l}\text { Can the results be applied to your patients/the population of } \\
\text { interest? The same results would likely apply in various } \\
\text { geographical regions due to the } 95 \% \text { confidence interval. }\end{array}$ & $\sqrt{ }$ & & \\
\hline $\begin{array}{l}\text { Can the test be applied to your patient or population of } \\
\text { interest? Yes. This study could be replicated for any geographical } \\
\text { location. }\end{array}$ & $\sqrt{ }$ & & \\
\hline $\begin{array}{l}\text { Were all outcomes important to the individual or population } \\
\text { considered? Yes. Greater variability of greenness was associated } \\
\text { with lower odds of both self-reported coronary heart disease and } \\
\text { hospitalizations from coronary heart disease. }\end{array}$ & $\sqrt{ }$ & & \\
\hline $\begin{array}{l}\text { What would be the impact of using this test on your } \\
\text { patients/population? Gaining an understanding of risk factors in } \\
\text { the development of coronary heart disease. Implementing } \\
\text { preventative strategies that include exercise and green spaces to } \\
\text { developing coronary heart disease. }\end{array}$ & $\mathrm{N} / \mathrm{A}$ & $\mathrm{N} / \mathrm{A}$ & $\mathrm{N} / \mathrm{A}$ \\
\hline
\end{tabular}


Table D4-

Study 4: Pereira, G., Christian, H., Foster, S., Boruff, B. J., Knuiman, M., Giles-Corti, B. (2013, June 9). The association between neighborhood greenness and weight status: An observational study in Perth Western Australia. Environmental Health, 12(29). http://doi:10.1186/1476-069X-12-49.

\begin{tabular}{|c|c|c|c|}
\hline 12 Questions & Yes & $\begin{array}{c}\text { Can't } \\
\text { Tell }\end{array}$ & No \\
\hline $\begin{array}{l}\text { Was there a clear question for the study to address? } \\
\text { Investigating the association between neighborhood green space } \\
\text { measured objectively using NDVI and weight status of overweight } \\
\text { or obese at different stages of adulthood. }\end{array}$ & $\sqrt{ }$ & & \\
\hline $\begin{array}{l}\text { Was there a comparison with an appropriate reference } \\
\text { standard? NDVI was calculated for } 1600-\mathrm{m} \text { around the } \\
\text { participant's residences. A participant was classified as obese if } \\
\text { they had a BMI }>30 \text {, and overweight if their BMI was }>25 \text {. } \\
\text { However, height and weight were used to calculate BMI and these } \\
\text { records were self-reported and therefore could have been falsified. }\end{array}$ & $\sqrt{ }$ & & \\
\hline $\begin{array}{l}\text { Did all patients get the diagnostic test and reference standard? } \\
\text { Yes. All participants were screened for BMI and greenness was } \\
\text { measured around their residence using NDVI }\end{array}$ & $\sqrt{ }$ & & \\
\hline $\begin{array}{l}\text { Could the results of the test have been influenced by the results } \\
\text { of the reference standard? No. NDVI is a standardized satellite } \\
\text { imagery tool and BMI is a standardized chart. }\end{array}$ & & & $\sqrt{ }$ \\
\hline $\begin{array}{l}\text { Is the disease status of the tested population clearly described? } \\
\text { Yes. Patients are clearly classified as either overweight or obese or } \\
\text { neither based on their reported BMI }\end{array}$ & $\sqrt{ }$ & & \\
\hline $\begin{array}{l}\text { Were the methods for performing the test described in } \\
\text { sufficient detail? } 10,208 \text { participants completed the Western } \\
\text { Australia Health and Wellbeing Survey between } 2004 \text { and } 2009 \text {. } \\
\text { Height and weight were self-reported by the participant. Age and } \\
\text { sex-specific BMI calculations were made. Participants were greater } \\
\text { than } 18 \text { years old. NDVI was obtained from Landsat imagery and } \\
\text { calculated around 1600-m of the participants' homes. }\end{array}$ & & $\sqrt{ }$ & \\
\hline $\begin{array}{l}\text { What are the results? Of the } 10,208 \text { total participants } 1,912 \\
\text { participants were classified as obese and } 5,459 \text { were classified as } \\
\text { overweight based on BMI calculations. Mean greenness for all } \\
\text { participants ranged from }-0.059 \text { to } 0.337 \text {. Variation of greenness } \\
\text { ranged from } 0.048-0.205 \text {. Adjusted odds ratios showed a } 16 \% \\
\text { decrease in reports of participants being overweight in areas of high } \\
\text { green space as opposed to a } 2 \% \text { decrease in areas with moderate } \\
\text { green space. Results were similar for reports of obesity with a } 22 \% \\
\text { decrease in obesity reports in areas of high green space as opposed } \\
\text { to an } 8 \% \text { decrease in moderate green space. Both overweight and } \\
\text { obese calculations showed a } 25 \% \text { decrease when observing areas of } \\
\text { high variability of green space. }\end{array}$ & $\mathrm{N} / \mathrm{A}$ & $\mathrm{N} / \mathrm{A}$ & $\mathrm{N} / \mathrm{A}$ \\
\hline
\end{tabular}




\begin{tabular}{|c|c|c|c|}
\hline $\begin{array}{l}\text { How sure are we about the results? Consequences and cost of } \\
\text { alternatives performed? Odds ratios were reported with a } 95 \% \\
\text { confidence interval. There were no additional costs since data had } \\
\text { been previously collected from the Western Australian Health and } \\
\text { Wellbeing Survey. }\end{array}$ & $\mathrm{N} / \mathrm{A}$ & N/A & $\mathrm{N} / \mathrm{A}$ \\
\hline $\begin{array}{l}\text { Can the results be applied to your patients/the population of } \\
\text { interest? Participants in this study were in western Australia, } \\
\text { however the results could be replicated in various geographic } \\
\text { regions. }\end{array}$ & $\sqrt{ }$ & & \\
\hline $\begin{array}{l}\text { Can the test be applied to your patient or population of } \\
\text { interest? This test could be applied to participants in any } \\
\text { geographic region. }\end{array}$ & $\sqrt{ }$ & & \\
\hline $\begin{array}{l}\text { Were all outcomes important to the individual or population } \\
\text { considered? Yes- Neighborhood greenness was associated with } \\
\text { decreased rates of obesity or overweight adults. }\end{array}$ & $\sqrt{ }$ & & \\
\hline $\begin{array}{l}\text { What would be the impact of using this test on your } \\
\text { patients/population? Additional risk factors for understanding the } \\
\text { development of increased BMI leading to overweight or obese } \\
\text { adults could be understood. }\end{array}$ & $\mathrm{N} / \mathrm{A}$ & $\mathrm{N} / \mathrm{A}$ & N/A \\
\hline
\end{tabular}


Table D5-

\begin{tabular}{|c|c|c|c|}
\hline $\begin{array}{l}\text { Study 5: Huang, W., Yang, B., Yu, H., Bloom, M.S., Markevych, I., } \\
\text { L,D., Leskinen, A., Dharmage, S.C., Jalaludin, B., Morawska, L., Jal } \\
\text { Lin, S., Zhou, Y., Liu, R., Feng, D., Hu, L., Zeng, X...Dong, G. (201 } \\
\text { between community greenness and obesity in urban-dwelling Chines } \\
\text { the Total Environment } 702 \text { (2020). http://doi.org/10.1016/j.scitotenv. }\end{array}$ & adult & $\begin{array}{l}\text { ociation } \\
\text { Scienc } \\
5040 \text {. }\end{array}$ & \\
\hline 12 Questions & Yes & $\begin{array}{l}\text { Can't } \\
\text { Tell }\end{array}$ & No \\
\hline $\begin{array}{l}\text { Was there a clear question for the study to address? The study } \\
\text { investigates if there is a relationship between residing in areas with } \\
\text { higher levels of green spaces and a decrease in the prevalence of } \\
\text { obesity and indicators of adiposity. }\end{array}$ & $\sqrt{ }$ & & \\
\hline $\begin{array}{l}\text { Was there a comparison with an appropriate reference } \\
\text { standard? All participants completed the same standardized survey } \\
\text { from the } 33 \text { Communities Chinese health study. Weight, height and } \\
\text { waist circumference was measured. BMI was calculated for an } \\
\text { indicator of obesity. BMI greater than } 30 \text { was defined as peripheral } \\
\text { obesity and central obesity was defined as a waist circumference } \\
\text { (WC) }>102 \mathrm{~cm} \text { in men and }>88 \mathrm{~cm} \text { in women. NDVI was calculated } \\
\text { in a } 100-\mathrm{m}, 500-\mathrm{m} \text {, and } 1000-\mathrm{m} \text { radius around the participants' } \\
\text { community centers. The NDVI that was calculated for } 500 \mathrm{~m} \text { around } \\
\text { the center was used in the final analysis of the study. }\end{array}$ & $\sqrt{ }$ & & \\
\hline $\begin{array}{l}\text { Did all patients get the diagnostic test and reference standard? } \\
\text { All participants were measured for BMI and WC. NDVI was } \\
\text { calculated in all of their communities. }\end{array}$ & $\sqrt{ }$ & & \\
\hline $\begin{array}{l}\text { Could the results of the test have been influenced by the results } \\
\text { of the reference standard? No. BMI and WC calculations for } \\
\text { obesity are standardized and participants were chosen at random. } \\
\text { NDVI is also a standardized measurement. }\end{array}$ & & & $\sqrt{ }$ \\
\hline $\begin{array}{l}\text { Is the disease status of the tested population clearly described? } \\
\text { BMI and WC measurements were calculated to determine obesity. }\end{array}$ & $\sqrt{ }$ & & \\
\hline $\begin{array}{l}\text { Were the methods for performing the test described in } \\
\text { sufficient detail? Yes. Participants completed a standardized } \\
\text { questionnaire to provide demographic information. Measurements } \\
\text { of height, weight and waist circumference were obtained during a } \\
\text { clinical examination. Definitions for obesity were taken from the } \\
\text { Working Group on Obesity in China. NDVI was calculated using } \\
\text { satellite imagery. The association between greenness and adiposity } \\
\text { excluded those participants who had a BMI }<18.5 \text {, history of } \\
\text { cardiovascular disease, or regularly adopted a low-calorie diet. } \\
\text { Results were adjusted for age, gender and household income. }\end{array}$ & $\sqrt{ }$ & & \\
\hline $\begin{array}{l}\text { What are the results? } 24,845 \text { participants enrolled in the study. } \\
\text { These participants are a subgroup who voluntarily enrolled from the } \\
33 \text { Communities Chinese Health Survey. NDVI values ranged from } \\
0.18 \text { to } 0.80 \text {. Mean BMI was calculated as } 24.40 \mathrm{~kg} / \mathrm{m} 2 \text { and mean }\end{array}$ & N/A & $\mathrm{N} / \mathrm{A}$ & $\mathrm{N} / \mathrm{A}$ \\
\hline
\end{tabular}




\begin{tabular}{|c|c|c|c|}
\hline $\begin{array}{l}\text { WC was } 83.24 \mathrm{~cm} \text {. Each } 0.17 \text { unit increase in NDVI was associated } \\
\text { with } 20 \% \text { lower odds for peripheral obesity and } 12 \% \text { lower odds for } \\
\text { central obesity. Confidence intervals for these reports were } 95 \% \text {. In } \\
\text { results adjusted for age, there was a stronger association between } \\
\text { NDVI and obesity correlation among older adult }>55 \text { years old than } \\
\text { with the younger participants ( } 18-55 \text { years old). }\end{array}$ & & & \\
\hline $\begin{array}{l}\text { How sure are we about the results? Consequences and cost of } \\
\text { alternatives performed? Confidence intervals of } 95 \% \text {. The results } \\
\text { of this study also compare to the results of other studies that have } \\
\text { investigated similar outcomes. Data was previously collected from } \\
\text { the } 33 \text { Communities Chinese Health Study so there were no } \\
\text { additional costs. }\end{array}$ & N/A & $\mathrm{N} / \mathrm{A}$ & $\mathrm{N} / \mathrm{A}$ \\
\hline $\begin{array}{l}\text { Can the results be applied to your patients/the population of } \\
\text { interest? The test would need to be applied to the population of } \\
\text { patients to determine if the results are translatable. }\end{array}$ & & $\sqrt{ }$ & \\
\hline $\begin{array}{l}\text { Can the test be applied to your patient or population of } \\
\text { interest? Yes. A similar test could be applied to any population of } \\
\text { patients. }\end{array}$ & $\sqrt{ }$ & & \\
\hline $\begin{array}{l}\text { Were all outcomes important to the individual or population } \\
\text { considered? Yes. The outcomes conclude that higher levels of } \\
\text { greenness correlate with lower incidence of central and peripheral } \\
\text { obesity }\end{array}$ & $\sqrt{ }$ & & \\
\hline $\begin{array}{l}\text { What would be the impact of using this test on your } \\
\text { patients/population? This study would allow a more clear } \\
\text { understanding of the causes of obesity in certain geographic } \\
\text { regions. Furthermore, understand the need to implement public } \\
\text { health and community measures to increase green spaces in order to } \\
\text { decrease rates of obesity. }\end{array}$ & N/A & $\mathrm{N} / \mathrm{A}$ & $\mathrm{N} / \mathrm{A}$ \\
\hline
\end{tabular}


Table D6-

Study 6: Yang, B., Markevych, I., Heinrich, J., Bowatte, G., Bloom, M.S., Guo, Y., Dharmage, S.C., Jalaludin, B., Knibbs, L.D., Morawska, L., Qian, Z., Chen, D., Ma, H., Chen, D., Lin, S., Yan, M., Liu, K., Zeng, X., Hu, 1., Dong, G. (2018, December 2). Associations of greenness with diabetes mellitus and glucose-homeostasis markers: The 33 Communities Chinese Health Study. International Journal of Hygiene and Environmental Health, 222 (2019), 283-290. http://doi.org/10.1016/j.ijheh.2018.12.001.

\begin{tabular}{|c|c|c|c|}
\hline 12 Questions & Yes & $\begin{array}{c}\text { Can't } \\
\text { Tell }\end{array}$ & No \\
\hline $\begin{array}{l}\text { Was there a clear question for the study to address? The study } \\
\text { investigates if living in spaces with higher levels of green space } \\
\text { leads to lower prevalence of diabetes mellitus in China. It also } \\
\text { investigates if there is an association between green spaces and } \\
\text { changes in glucose-homeostasis markers that can lead to diabetes } \\
\text { development. }\end{array}$ & $\sqrt{ }$ & & \\
\hline $\begin{array}{l}\text { Was there a comparison with an appropriate reference } \\
\text { standard? Participants in the study underwent an overnight fasting } \\
\text { of } 12 \text { hours and then had a standard } 75-\mathrm{g} \text { oral glucose tolerance test } \\
\text { performed. Blood samples were drawn at zero and two hours after } \\
\text { the glucose intake. Fasting and two-hour glucose and insulin levels } \\
\text { were determined using and enzymatic colorimetric method and } \\
\text { immune-assay respectively. Residential greenness was defined } \\
\text { using NDVI in } 100-\mathrm{m}, 500-\mathrm{m} \text {, and } 1000 \text {-m areas around each } \\
\text { participant's community center. }\end{array}$ & $\sqrt{ }$ & & \\
\hline $\begin{array}{l}\text { Did all patients get the diagnostic test and reference standard? } \\
\text { Yes. All participants underwent the blood testing and had NDVI } \\
\text { calculated around their community centers. }\end{array}$ & $\sqrt{ }$ & & \\
\hline $\begin{array}{l}\text { Could the results of the test have been influenced by the results } \\
\text { of the reference standard? No. Participants voluntarily } \\
\text { participated in the study and were chosen at random from the } 33 \\
\text { Communities Chinese Health Study. }\end{array}$ & & & $\sqrt{ }$ \\
\hline $\begin{array}{l}\text { Is the disease status of the tested population clearly described? } \\
\text { Yes. The participants in the study were being assessed for history of } \\
\text { diabetes mellitus. }\end{array}$ & $\sqrt{ }$ & & \\
\hline $\begin{array}{l}\text { Were the methods for performing the test described in } \\
\text { sufficient detail? Yes. Fasting and two-hour blood glucose and } \\
\text { insulin levels were drawn following an oral glucose tolerance test. } \\
\text { Insulin resistance was calculated using the homeostasis model } \\
\text { assessment of insulin resistance. Beta cell function was determined } \\
\text { using the homeostasis model assessment of beta cell function. } \\
\text { Diabetes mellitus was defined per the American Diabetes } \\
\text { Association as fasting glucose of }>7.0 \mathrm{mmol} / \mathrm{L} \text { or two-hour glucose } \\
>11.0 \mathrm{mmol} / \mathrm{L} \text {, or the use of an anti-diabetic medication. Greenness } \\
\text { was calculated using NDVI. Air pollution was measured by } \\
\text { assessing nitrogen dioxide levels determined from monitoring }\end{array}$ & $\sqrt{ }$ & & \\
\hline
\end{tabular}




\begin{tabular}{|c|c|c|c|}
\hline $\begin{array}{l}\text { stations. Main models were adjusted for age, sex, ethnicity, income } \\
\text { and educational levels. }\end{array}$ & & & \\
\hline $\begin{array}{l}\text { What are the results? } 15,477 \text { participants were included in the } \\
\text { final analysis of the study. } 13,783 \text { participants did not have diabetes } \\
\text { mellitus. } 1,694 \text { participants were positive for diabetes mellitus. An } \\
\text { NDVI increase of } 0.1 \text {-unit was associated with } 12 \% \text { lower odds for } \\
\text { prevalence of diabetes. It was also associated with } 1.14 \% \text { lower } \\
\text { fasting glucose and a } 2.03 \% \text { lower two-hour glucose, } 1.66 \% \text { lower } \\
\text { two-hour insulin and } 1.17 \% \text { lower insulin resistance and } 3.33 \% \\
\text { higher beta-cell function. Greenness and beta cell function was } \\
\text { independent from levels of air pollution. Fasting glucose, two-hour } \\
\text { glucose and rates of diabetes were partially due to lower air } \\
\text { pollution. }\end{array}$ & $\mathrm{N} / \mathrm{A}$ & $\mathrm{N} / \mathrm{A}$ & $\mathrm{N} / \mathrm{A}$ \\
\hline $\begin{array}{l}\text { How sure are we about the results? Consequences and cost of } \\
\text { alternatives performed? The data was reported with } 95 \% \\
\text { confidence intervals. }\end{array}$ & $\mathrm{N} / \mathrm{A}$ & $\mathrm{N} / \mathrm{A}$ & $\mathrm{N} / \mathrm{A}$ \\
\hline $\begin{array}{l}\text { Can the results be applied to your patients/the population of } \\
\text { interest? Further testing would need to be completed in order to } \\
\text { understand if these results would be applicable in areas outside of } \\
\text { the } 33 \text { Communities Chinese Health Study. }\end{array}$ & & $\sqrt{ }$ & \\
\hline $\begin{array}{l}\text { Can the test be applied to your patient or population of } \\
\text { interest? Yes. This test could be replicated and applied to } \\
\text { participants in any geographic region. }\end{array}$ & $\sqrt{ }$ & & \\
\hline $\begin{array}{l}\text { Were all outcomes important to the individual or population } \\
\text { considered? Yes. Outcomes of the study suggest various proposals } \\
\text { to enhance green spaces in Chinese communities in order to } \\
\text { improve air quality and potentially increase physical activity, which } \\
\text { can lead to decreased prevalence of diabetes mellitus. }\end{array}$ & $\sqrt{ }$ & & \\
\hline $\begin{array}{l}\text { What would be the impact of using this test on your } \\
\text { patients/population? This test would be helpful to understand } \\
\text { populations at risk of developing diabetes mellitus and implement } \\
\text { community and public health changes to include increased green } \\
\text { spaces as a way to prevent the development of diabetes mellitus. }\end{array}$ & $\mathrm{N} / \mathrm{A}$ & $\mathrm{N} / \mathrm{A}$ & $\mathrm{N} / \mathrm{A}$ \\
\hline
\end{tabular}




\section{Appendix E}

Cross Study Analysis

Table E-

\begin{tabular}{|c|c|c|c|}
\hline Title and Author & NDVI level & Overall Physiologic Outcome & $\begin{array}{c}\text { Outcome Negative or } \\
\text { Positive }\end{array}$ \\
\hline Study 1: James et al., 2016 & $\begin{array}{l}0.29+/-0.08-0.62+/-0.05 \text { in } \\
\text { a } 250 \mathrm{~m} \text { radius around the } \\
\text { participants' homes. }\end{array}$ & $\begin{array}{l}12 \% \text { lower all-cause } \\
\text { mortality in participants who } \\
\text { lived in the highest quintile of } \\
\text { NDVI. }\end{array}$ & $\begin{array}{l}\text { Positive outcome. Increased } \\
\text { green space was associated } \\
\text { with lower all-cause mortality } \\
\text { rates. }\end{array}$ \\
\hline Study 2: Yeager et al., 2018 & $\begin{array}{l}\text { NDVI was classified as high } \\
(>0.55) \text {, medium }(0.36-0.54) \\
\text { and low }(<0.36) \text { at } 250-\mathrm{m} \\
\text { around the participants' } \\
\text { homes. }\end{array}$ & $\begin{array}{l}\text { Increased NDVI was } \\
\text { associated with lower urine } \\
\text { levels of catecholamines and } \\
\text { isoprotanes. Increased NDVI } \\
\text { was also associated with a } \\
\text { positive correlation between } \\
\text { angiogenic cells responsible } \\
\text { for wound and tissue repair, } \\
\text { suggesting that those who } \\
\text { live close to green spaces } \\
\text { have greater chances of faster } \\
\text { recovery from CVD damage. }\end{array}$ & $\begin{array}{l}\text { Positive outcome. Increased } \\
\text { green space was associated } \\
\text { with lower rates of } \\
\text { cardiovascular disease and its } \\
\text { markers. }\end{array}$ \\
\hline $\begin{array}{l}\text { Study 3: Pereira, Foster, et } \\
\text { al., } 2012\end{array}$ & $\begin{array}{l}0.068-0.096 \text { in a } 1600 \mathrm{~m} \\
\text { radius around participants' } \\
\text { homes. NDVI variability was } \\
\text { also calculated }\end{array}$ & $\begin{array}{l}\text { Greater variability of } \\
\text { greenness was associated } \\
\text { with lower odds of self- } \\
\text { reported heart disease or } \\
\text { stroke and hospitalization } \\
\text { with heart disease or stroke. } \\
\text { Mean level of greenness did } \\
\text { not show statistical } \\
\text { significance for physiologic }\end{array}$ & $\begin{array}{l}\text { Positive outcome. Increased } \\
\text { green space was associated } \\
\text { with decreased } \\
\text { hospitalization for heart } \\
\text { disease or stroke. }\end{array}$ \\
\hline
\end{tabular}




\begin{tabular}{|l|l|l|l|}
\hline & & outcome. & \\
\hline $\begin{array}{l}\text { Study 4: Pereira, Christian, et } \\
\text { al., 2013 }\end{array}$ & $\begin{array}{l}-0.059 \text { to a high of } 0.337 . \\
\text { Variation of greenness was } \\
\text { also measured and ranged } \\
\text { from } 0.048 \text { to } 0.205 .\end{array}$ & $\begin{array}{l}16-25 \% \text { lower rates of } \\
\text { overweight/obese and obese } \\
\text { participants in areas of high } \\
\text { greenness. 25\% decrease in } \\
\text { overweight/obese and obese } \\
\text { participants in areas of high } \\
\text { variability of greenness. }\end{array}$ & $\begin{array}{l}\text { Preen space was associated } \\
\text { with lower rates of obesity. }\end{array}$ \\
\hline $\begin{array}{l}\text { Study 5: Huang W.Z. et al., } \\
2019\end{array}$ & $\begin{array}{l}\text { 0.18-0.80 in a 500m radius } \\
\text { around participants' homes. } \\
\text { peripheral obesity. }\end{array}$ & $\begin{array}{l}\text { Positive outcome. Increased } \\
\text { green space was associated } \\
\text { with lower rates of obesity. }\end{array}$ \\
\hline Study 6: Yang et al., 2018 & $\begin{array}{l}0.18 \text { to 0.80 in 500-m radius } \\
\text { around participants' homes. }\end{array}$ & $\begin{array}{l}\text { Decrease in rates of diabetes, } \\
\text { insulin and glucose levels, } \\
\text { insulin resistance and } \\
\text { increase in beta cell function } \\
\text { was noted for each 0.1 unit } \\
\text { increase in NDVI }\end{array}$ & $\begin{array}{l}\text { Positive outcome. Increased } \\
\text { green space was associated } \\
\text { with lower rates of diabetes. }\end{array}$ \\
\hline
\end{tabular}

